\title{
ROMAN PORTS IN THE LOWER TIBER VALLEY: COMPUTATIONAL APPROACHES TO REASSESS ROME'S PORT SYSTEM
}

\author{
by Maria del Carmen Moreno Escobar
}

\begin{abstract}
This paper presents an innovative study of the port system of Rome in Imperial times through the application of an integrated approach to both archaeological analysis and material evidence. Specifically, it seeks to provide a more complete contextualization and understanding of the port system of Rome by focusing on the exploration of the physical geography of the river Tiber and its transformations in connection with the organization of the port system between the late first century $B C$ and early third century $A D$. Methodologically, this study is based on the compilation, re-evaluation and analysis of published archaeological and geoarchaeological data and on the application of modelling and simulations techniques within a GIS environment. These foundations and means allow us to reconstruct the development of the river Tiber's historical course in antiquity and its impact on specific organizational aspects of Rome's port system. In this sense, this study provides new insights and avenues of research (applicable to other geographical areas and periods of time) to evaluate the system's changing capacity for transport and the potential existence of a signalling system, in contrast to previous hypotheses on the organization of river traffic along the Tiber.
\end{abstract}

Questo contributo presenta uno studio innovativo del sistema portuale di Roma in epoca imperiale attraverso l'applicazione di un approccio integrato sia dell'analisi archeologica sia delle evidenze materiali. In particolare, si propone di fornire una contestualizzazione più completa e una comprensione del sistema portuale di Roma focalizzandosi sull'esplorazione della geografia fisica del Tevere e delle sue trasformazioni in connessione con l'organizzazione del sistema portuale tra il tardo I secolo a.C. e gli inizi del III secolo d.C. Dal punto di vista metodologico, lo studio si basa sulla compilazione, rivalutazione e analisi di dati archeologici e geoarcheologici pubblicati e sull'applicazione di tecniche di modellazione e simulazione in ambiente GIS. Queste basi documentali e questi strumenti consentono di ricostruire lo sviluppo del corso del fiume nell'antichità e il suo impatto su specifici aspetti organizzativi del sistema portuale di Roma. Da questo punto di vista il presente studio fornisce nuovi spunti e apre nuovi filoni di ricerca (applicabili ad altre aree geografiche e periodi di tempo) ai fini di valutare la capacità di cambiamento del sistema di trasporto e la potenziale esistenza di un sistema di controllo, in contrasto con le precedenti ipotesi sull'organizzazione del traffico fluviale lungo il Tevere.

\section{DISPERSION VS INTEGRATION: THE PORT SYSTEM OF IMPERIAL ROME IN ITS HISTORIOGRAPHICAL CONTEXT}

Rome's conquest of territories beyond its immediate surroundings generated a vast political entity whose cohesion was ensured by a network of terrestrial and maritime routes. This made possible the integration of distant areas into a 
single system controlled and organized by Rome as head of its empire, resulting in the profound transformation of both the city and its citizens. These transformations, visible in the city and its growth during the late Republic and early Empire (C. Smith, 2018), also affected Rome's supply system: to ensure the uninterrupted flow of foodstuffs and goods between the Imperial capital and the provinces, the Roman authorities developed a transport system based on the interconnection via the river Tiber of several fluvial ports in Rome and Ostia (and later on, also Portus), elements that constituted the axis and nodes of Rome's port system (Fig. 1).

Many of these elements have long been identified and studied, thanks to the strong tradition of antiquarian and archaeological research in the Tiber valley, which has generated an outstanding volume of information about its occupation and development. More interestingly, more recent research in the area has applied interdisciplinary approaches to reassess the characteristics and temporal development of specific sites, such as Portus (Keay et al., 2005b; Keay and Paroli, 2011; Keay, 2012), Ostia (Meiggs, 1973; Pavolini, 2006; Salomon et al., 2016) and the Emporium (Mocchegiani Carpano, 1995), or small areas such as quartiere ostiense (Roggio, 2010), ex Mercati Generalli (Mellace et al., 2011) or Fiume Morto near Ostia. This new wealth of information emphasizes

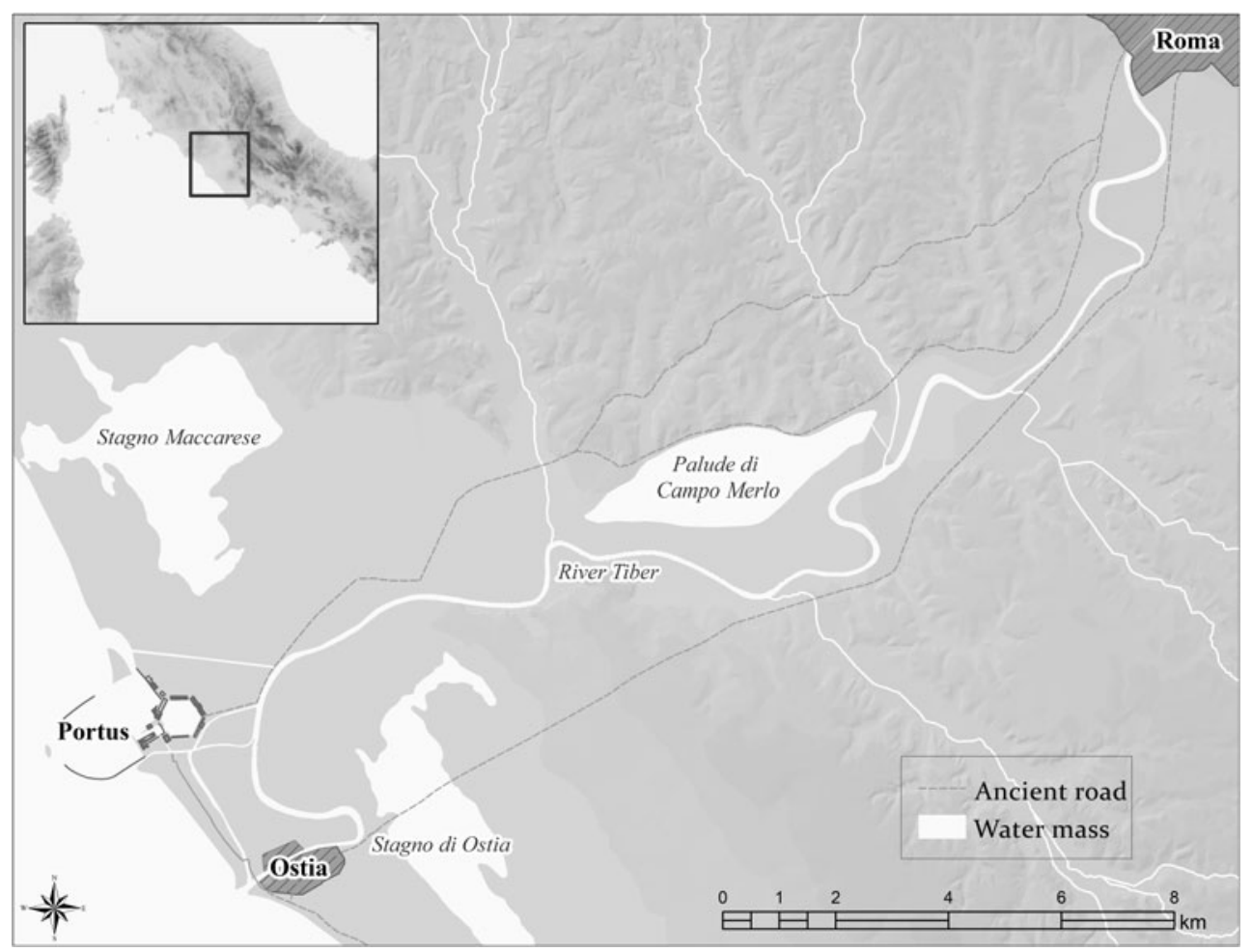

Fig. 1. Main nodes and elements in the port system of Imperial Rome (Moreno Escobar). 
the singularity and complexity of these sites, but it also runs the risk of partially masking their sense of belonging to a larger port system (by focusing on the parts, we may fail to fully understand the whole). Fortunately, recent trends in research are beginning to integrate this new evidence (Rice, 2018) and to explore the structure and temporal development of the system, as well as the interactions between its elements. Some of the varied approaches applied to this topic include:

(1) geographical perspectives, such as the analysis by Boetto (2016), where she applies the concept of transport zones to Rome's port system to connect the archaeological evidence of ports and warehouses with the characteristics of water masses and boats, thus offering insightful hypotheses about its regional organization and the role of specific nodes as transit points;

(2) topographical perspectives, such as the work by Pensabene and Domingo $(2017,2018)$, where they integrated the evidence about ports and warehouses along the Tiber and Rome's urban topography as a means of exploring the complexities of monumental building in Trajanic times, particularly focusing on the transport of column shafts from their origin until their placement in Rome;

(3) historical perspectives, such as the study by Malmberg (2015), combining the analysis of literary, iconographic and epigraphic evidence with the study of Rome's port infrastructure and urbanism in Rome to offer a diachronic assessment of the changing configuration of the city and its relationship with the Tiber; (Interestingly, this work also proposes some hypotheses about the organization of the river traffic and the role of roads and warehouses at Ostia and Portus.)

(4) archaeological perspectives, such as the diachronic analysis of the elements integrating Rome's port system by Keay (2016), which provides a much-needed overview of their interrelations and temporal development and a reassessment of the system's role as commercial node in the Mediterranean.

Regardless of their perspective, these examples constitute clear evidence of how the integration of different approaches and data can help to answer both old and new questions. The research presented in this paper stems directly from this context, and approaches the analysis of Rome's port system from the perspective of spatial analysis and computing applications. By placing the focus on the integration of geoarchaeological and archaeological data within digital environments, this paper seeks to provide a better understanding of the changes in the Tiber's course and how these affected the structure and organization of Rome's port system, attending to three specific aspects: (1) the organization of river traffic between Rome, Ostia and Portus (with a particular interest in testing the hypothesis proposed by Malmberg); (2) the estimation of the system's transport capacity and how it changed in connection with the development of port infrastructure; and (3) the existence of a signalling system for river navigation. In doing so, this paper addresses questions that could not be successfully approached using other more traditional methods, thus opening up new topics of research in the region. 


\section{RECONSTRUCTING THE PORT SYSTEM: METHODS AND EVIDENCE}

Regardless of its focus, the long tradition of antiquarian and archaeological research in the Tiber valley has produced an outstanding volume of information about its occupation, currently scattered across innumerable publications and archives but whose potential for research in the region is indisputable. The (re)use of this information presents, nonetheless, important challenges due to its dispersion, volume, nature and (not least) the different times at which, and methods by which, it was produced, characteristics that ultimately result in a highly heterogeneous data set. This complexity does not necessarily represent a disadvantage for research, as previous initiatives have demonstrated (J.T. Smith, 1997; Hidalgo Prieto, 2016). On the contrary, and despite its heterogeneity, it offers outstanding potential for generating new interpretations based on the reassessment and reanalysis of this old data within new methodological frameworks (e.g. computing applications) and from different perspectives (e.g. landscape archaeology). The research presented in this paper develops within these frameworks and is grounded on an integrated analysis of heterogeneous data through computational methods that relies on a dual basis: first, on the compilation and reassessment of archaeological and geoarchaeological information, previously scattered across publications and archives and now integrated into the Ager et Portus Tiberis information resource (APT); and secondly, on the use of techniques of digital modelling and spatial analysis within GIS environments to explore and analyse the ancient topography and occupation of the lower Tiber valley.

These approaches are applied within a theoretical understanding of Rome's supply system that combines the concepts of port system and territory to explore its complexity. A port system is a conceptual model that integrates all port infrastructure and facilities, as well as all sites related to port activity, in combination with the areas of interface between land and water, where port activities could take place (Carayon, 2018). However, port systems are not isolated entities within regions. On the contrary, they are integrated into the territorial structures developed by local communities over their surroundings (Moreno Escobar, 2020). As a result, the defining nature of port systems as conceptual entity and territorial model emerges from their unique context: the meeting place of land and water. These considerations are more relevant for Rome, due to two important particularities in terms of its geography:

(1) Rome can be considered a maritime city despite not hosting a sea port within its boundaries: its inland location, nearly $27 \mathrm{~km}$ from the sea, has not prevented it from having a character as a maritime port, which is only possible through its connection to the Mediterranean by the river Tiber.

(2) Rome can be considered a città di primo-ponte (a 'first-bridge city') (Le Gall, 2005: 48-50), where terrestrial communications crossing the river and fluvial and maritime communications through the river met, thus highlighting the role of Rome as a multi-modal crossroads. 
Consequently, it is clear that attention must be paid both to elements related to port activities and to other sites and structures in the area as clear indications of the territorialization ${ }^{1}$ of the Tiber valley in Imperial times and of the creation and development of the port system of Imperial Rome.

One of the first challenges in this research was to unite all the dispersed information about the structure and occupation of the lower Tiber valley into a single resource, including both archaeological and geoarchaeological data. This was achieved through the use of database management systems (DBMS) and Geographic Information Systems (GIS), tools that are becoming increasingly common in archaeological research for spatial analysis (Scheidel and Meeks, 2012; Moreno Escobar and Wheatley, 2016; López-Mondéjar, 2019) and for data management, data reuse and archival purposes (Moreno Escobar and García Sanjuán, 2013; Buzón Alarcón et al., 2016; Ark, ${ }^{2}$ the Digital Atlas of Roman and Medieval Civilizations $\left.{ }^{3}\right)$. Their main interest resides in their potential for compiling, structuring, visualizing and analysing vast and complex data sets, both spatially and temporally, but (more interestingly) they are especially suitable for evaluating and testing hypotheses through models and simulations (Brughmans et al., 2019). Therefore, a relational DBMS ${ }^{4}$ and a GIS $^{5}$ were developed as infrastructure of the APT to compile information about the organization and occupation of the lower Tiber valley and the river Tiber in Imperial times. This resource stores information about archaeological sites and structures, and water masses and land/water interfaces in the period between the late first century $\mathrm{BC}$ and the early third century $\mathrm{AD}$ (Table 1). More specifically, the APT database was designed to deal with the considerable heterogeneity of this evidence through re-evaluating it within a standardized typological categorization at two levels of analysis (i.e. generic and specific) based on the finds and materials found at each location (Table 2). The database was then populated through a process of bibliographic and archival review $^{6}$ carried out during my postdoctoral research period at the British School at Rome, during which I made extensive use of the libraries at this and other research institutions in Rome and got in touch with researchers and

\footnotetext{
1 The process by which territories are considered managed spaces in continuous transformation for their adaptation to the changing needs of the communities that inhabit them (Zoido Naranjo et al., 2000, territorialización). For its application in archaeology, see Moreno Escobar, Ojeda Rivera and García Sanjuán, 2020.

2 http://ark.portusproject.org (accessed 25 April 2016).

3 https://darmc.harvard.edu (accessed 10 February 2020).

4 This database was implemented in Microsoft Access version 2016 and followed the conceptual model of the Rome's Mediterranean Ports Project Database.

5 Developed in ESRI ArcGIS, version 10.1.

6 A more detailed discussion of both the structure of the APT resource and the data compilation process is developed in a forthcoming publication focusing on the territorial development of the lower Tiber valley in Imperial times, currently in preparation.
} 
Table 1. Periodization employed to classify the sites compiled in the APT information resource (Moreno Escobar).

\begin{tabular}{ll}
\hline Chronological period & Temporal extent \\
\hline Period 1 & Augustan to pre-Claudian (c. 27 BC-AD 40) \\
Period 2 & Claudian to Flavian (c. 40-100) \\
Period 3 & Trajanic and Hadrianic $(c .100-140)$ \\
Period 4 & Antonines (c. 140-190) \\
Period 5 & Severan $(c .190-235)$ \\
\hline
\end{tabular}

Table 2. Categories of functional typology ascribed to the archaeological sites compiled in the project database and examples of evidence included in each category (Moreno Escobar).

\begin{tabular}{ll}
\hline Generic typology & Specific typology \\
\hline $\begin{array}{l}\text { Settlement } \\
\text { Funerary }\end{array}$ & Cities, towns, villae, rural settlements ... \\
$\begin{array}{l}\text { Sacred structures and } \\
\text { places }\end{array}$ & $\begin{array}{l}\text { Tecropolis, isolated burials, funerary monuments ... } \\
\text { Productive activities }\end{array}$ \\
Storage and trade & Glass workshops, kilns, quarries, fish farming facilities ... \\
Port infrastructure & Warehouses, storerooms, tabernae ... \\
Road infrastructure & Moles, landings, quays, lighthouses ... \\
Infrastructure & Road sections, stationes, bridges ... \\
Urban infrastructure & Territorial markers (e.g. cippi). \\
Water infrastructure & Cisterns, water drainage ... \\
Other & Inscriptions, honorific monuments, dumping sites .... \\
Undefined & Building structures and scatters of finds on surface offering insufficient \\
& information to formulate an interpretation. \\
\hline
\end{tabular}

specialists at other European academies and institutes across the city, ${ }^{7}$ who greatly helped in the identification of relevant data sources.

This process of data-gathering resulted in the identification and mapping of 170 archaeological sites and 145 isolated structures that partially illustrate the structure of occupation in the lower Tiber valley, as well as 10 specific areas where a substantial transformation of the river course occurred in the period under study (Fig. 2). The present paper will mainly use geoarchaeological and geographical evidence to explore the implications of how the transformations and changes of the river course impacted the organization of the port system. The complete analysis of the archaeological evidence from the perspective of spatial and territorial organization will be developed in a different publication, currently in preparation. However, a preliminary analysis of the archaeological

7 I would like to specially thank Prof. Simon Keay, Dr Dragana Mdladenovic and Prof. Christopher Smith for their help and guidance in navigating the wide variety of archaeological sources, and Renato Sebastiani, Renato Matteucci and Carlo Rosa for their help and support in the process of geoarchaeological data compilation. Their cooperation was most valuable and appreciated. 


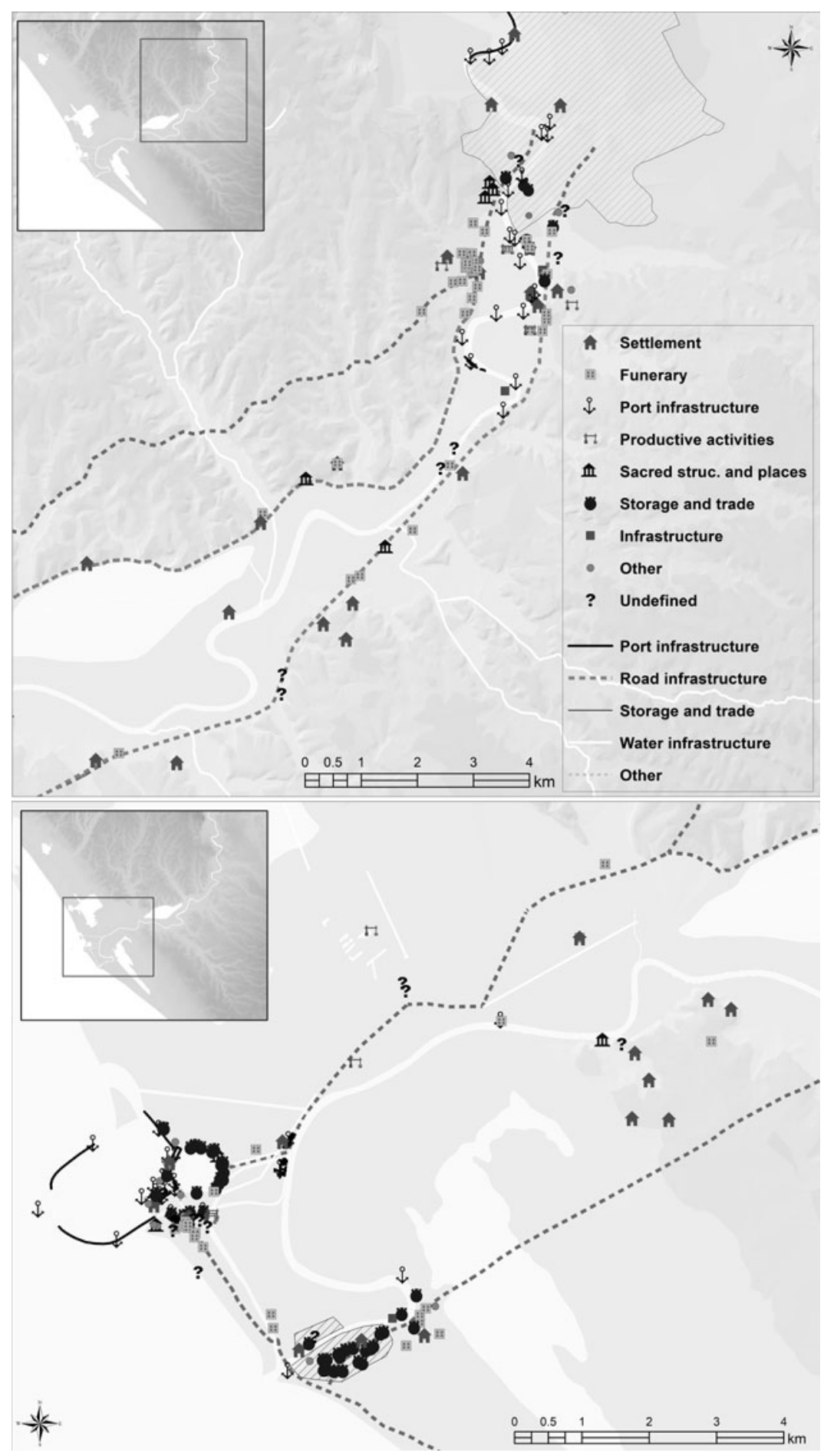

Fig. 2. Distribution map of the archaeological sites and structures identified in the lower Tiber valley between the late first century BC and the early third century $\mathrm{AD}$ (Moreno Escobar). 
evidence is also presented here as a means of identifying general trends of occupation in the area that can contribute to understanding the development of the port system of Imperial Rome.

This analysis permits us to identify some interesting dynamics in the occupation of the lower Tiber valley between the late first century BC and midthird century AD. Firstly, the higher number of sites identified in the area over time is evidence of an increasing intensity of occupation, a trend that peaks in period 4 (Fig. 3). This intensity of occupation could be linked to the population growth that Rome experienced during the first centuries of the Empire (Lo Cascio, 2018), possibly in connection with its pull over the population of other regions in the Italian peninsula (Witcher, 2005), thus showing how this process developed both within Rome's urban limits and in its hinterland and affected other population centres in the area, such as Ostia and Portus. Secondly, this increasing occupation seems to be articulated around the main communication axes in the lower Tiber valley, namely the Via Campana/Portuensis, the Via Ostiensis, the Via Flavia and the river Tiber, as around 50 per cent of the sites identified in the area lie within $100 \mathrm{~m}$ of either roads or river. More interestingly, using this data makes it possible to explore the degree of transformation in the area's occupation by attending to the sites' lifespan through time: through their quantification as percentages of abandonment, continuity and new foundations, we may establish comparisons across periods,

\section{0}

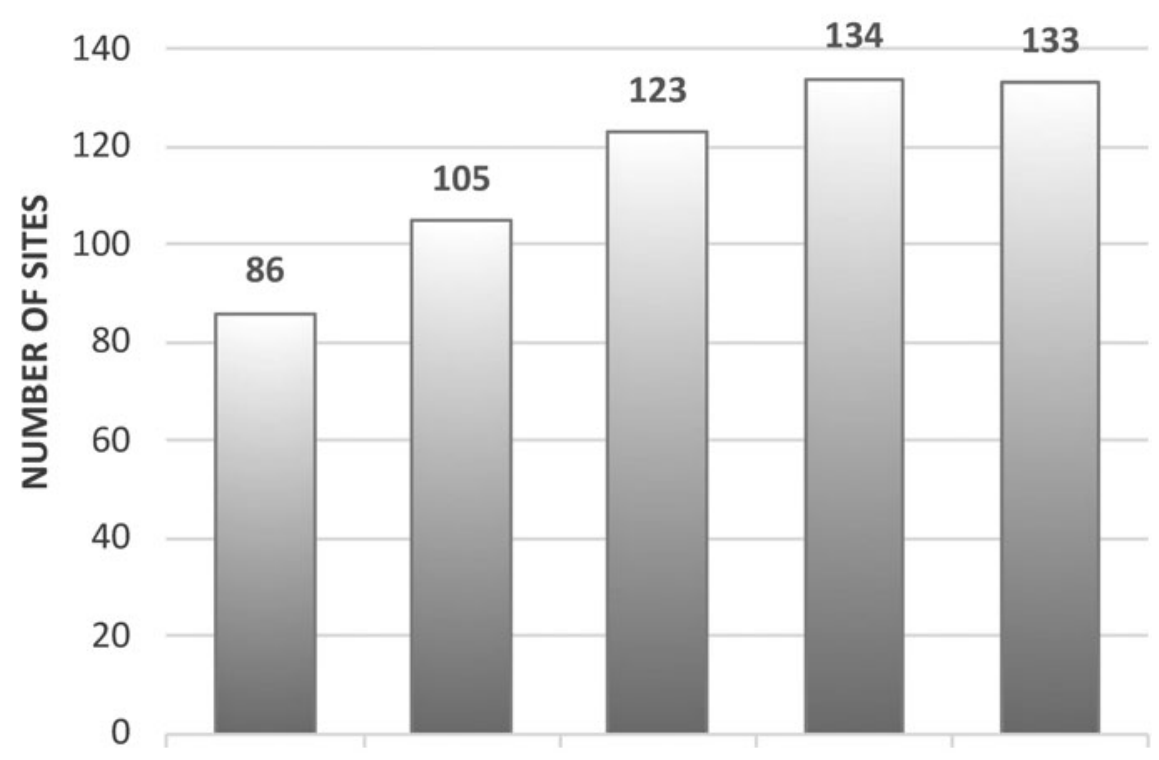

Period 1 Period 2 Period 3 Period 4 Period 5

Fig. 3. Number of sites identified in each period in the Tiber valley

(Moreno Escobar). 


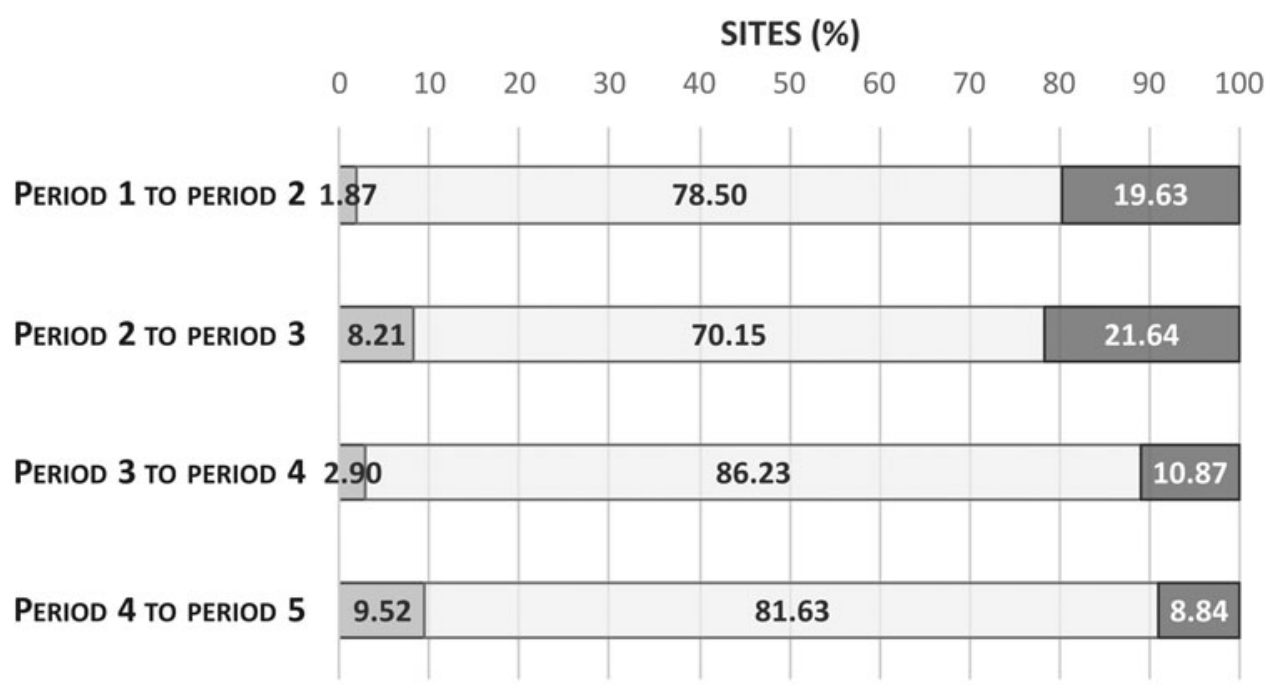

$\square$ Abandoned $\square$ Continued $\square$ New

Fig. 4. Percentage of sites abandoned (left), continuing from the previous period (centre), and newly founded (right) in the periods under study (Moreno Escobar).

regardless of the number of sites identified (Fig. 4), which may create some unexpected possibilities of a deeper understanding of this area's territorial development in Imperial times.

Following this procedure, we can observe in the transition from period 1 to period 2 a very low percentage of abandonments ( 1.87 per cent) and a very high percentage of new foundations (19.63 per cent), indicative of an expansion of the occupation system that continues its previous development. In this sense, it supports the interpretation of the Claudian foundation of Portus as an additional part of the ongoing port and territorial system in the lower Tiber valley, which (nonetheless) had a substantial impact on the whole. The transition from period 2 to period 3 suggests a substantial change in the pattern of occupation in the Tiber valley, evidenced in the high percentage of sites ceasing their activity (8.21 per cent) and the very high percentage of new foundations (21.64 per cent) in the area. These highlight the profound disruption that the Trajanic interventions had wrought on the previous pattern of occupation, further emphasized by the lowest percentage of continuity registered across all periods ( 70.15 per cent). In contrast, the transition from period 3 to period 4 shows strong elements of continuation of the previous pattern of occupation, with a moderately high percentage of new foundations (10.87 per cent) and a very low percentage of sites ceasing their activity (2.90 per cent). This may be interpreted as evidence of the relatively few modifications introduced into the port system under the Antonines, which seem to have focused on increasing the storage capacity of the port system by either building new warehouses or expanding the capacity of existing ones, as 
suggested in previous research (Keay and Millett, 2005b). Finally, the transition from period 4 to period 5 presents possibly the most interesting situation in the whole period under study: although the percentage of continuity is the second highest in the series, thus indicating a general continuation of the occupation pattern from the previous period, the data contain some hints of potential changes, such as a reversal of the relationship between the ratios of new and abandoned sites in each of the previous periods. Thus, we can observe that the percentage of sites abandoned is not only the highest in the series $(9.52$ per cent), but also higher than the percentage of new sites (8.84 per cent) (also the lowest across the periods). It is important to clarify, nonetheless, that this difference, which in essence is quite small (less than 1 per cent, representing only 1 site in absolute terms), becomes more meaningful when it is contextualized within the wider temporal scope under analysis: when the difference between new foundations and abandoned sites is computed for all periods $(+17.76$ per cent between period 1 and period $2 ;+13.43$ per cent between period 2 and period 3; +7.97 per cent between period 3 and period 4; and -0.68 per cent between period 4 and period 5), a new general trend becomes visible, showing how the expansion of the system may not only be decelerating through time but even retracting in the final period under study. Despite the undeniable interest of this possibility (which may open new avenues of research into the transformation of Rome and its hinterland in late antiquity), its exploration requires further work that falls outside the framework and scope of the present research.

\section{RECONSTRUCTING THE RIVER: GEOARCHAEOLOGY, ARCHAEOLOGY AND COMPUTERS}

The previous sections have highlighted the fundamental role that the Tiber played in the creation and organization of Rome's port system, but more importantly they emphasize the need for a full understanding of the geography and transformations of the river in antiquity as the prerequisite to understanding the port system.

Much research has explored the geographical dimension of the Tiber across history, through geoarchaeological cores (Mellace et al., 2011), GIS hydrological modelling (Ascani et al., 2008) and historical maps (Taylor, 2018), amongst other approaches. Their scale of analysis has been predominantly local, but they have succeeded in identifying several areas where the Tiber changed its course in antiquity (Fig. 5): within the city, in the Campo Marzio (Leonardi et al., 2010; Taylor, 2018; Fig. 5.1), in the surroundings of ex Mercati Generali (Mellace et al., 2011) (Fig. 5.2) and in the vicinity of the current river course, where multiple remains of port infrastructure have been located (Moccheggiani Carpano, 1981; Fig. 5.3); between Rome and the sea, in the meander of Magliana and the former palude di Campo Merlo (Catalli, 


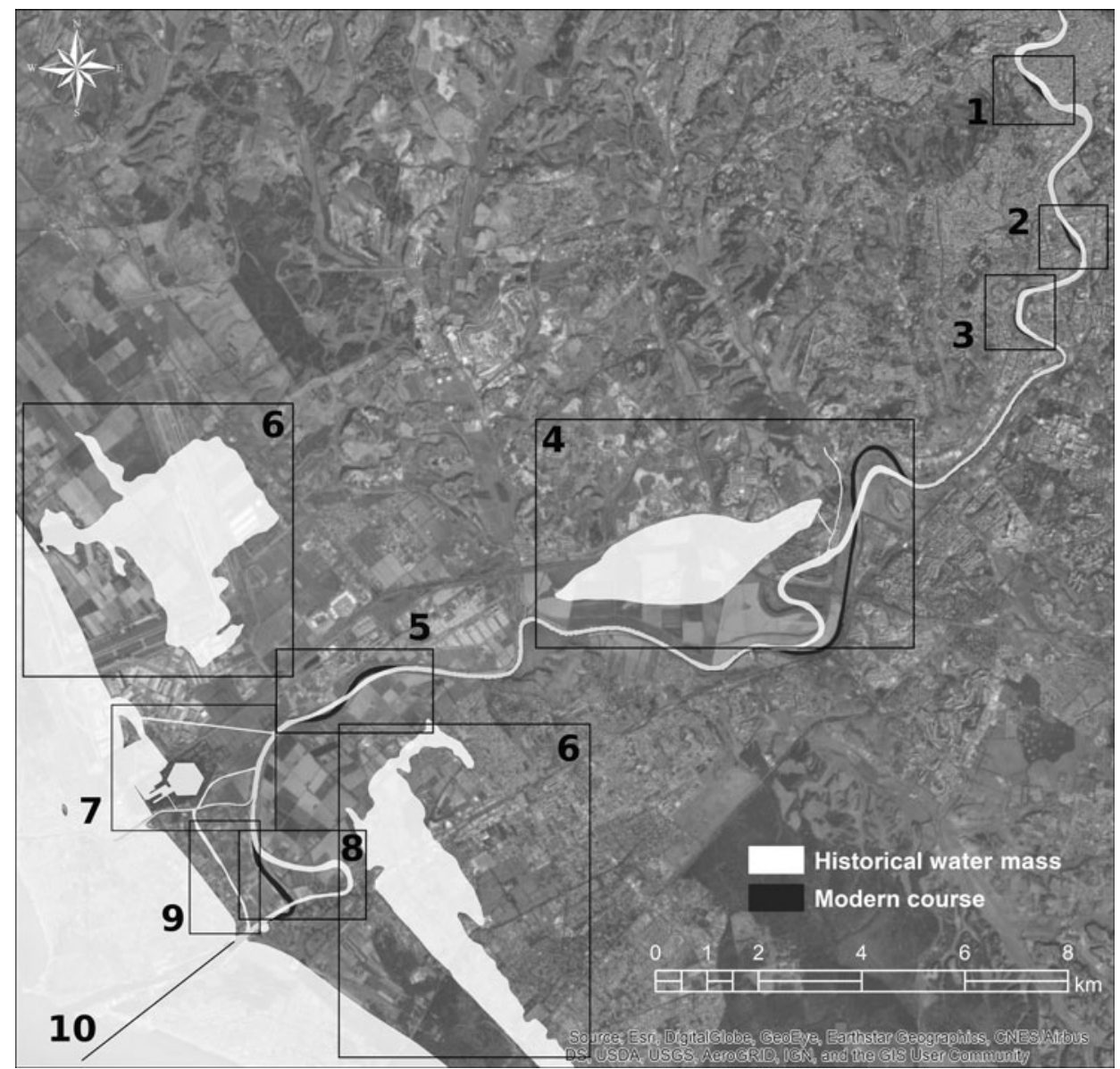

Fig. 5. Areas where changes in the Tiber course in antiquity have been identified (Moreno Escobar. Basemap source: ESRI, Digital Globe, GeoEye, Earthstar Geographics, CNES/Airbus DS, USDA, USGS, AEX, Getmapping, Aerogrid, IGN, IGP, swisstopo, and the GIS User Community).

Coletti and Arnoldus-Huyzendveld, 1995; Fig. 5.4), the area of Ponte Galeria and Fiera di Roma (Arnoldus-Huyzendveld, 2014; Fig. 5.5), the areas formerly occupied by the stagno di Ostia and stagno Maccarese (Amenduni, 1884; Fig. 5.6), the canal network near Portus (Keay, Millett and Strutt, 2005a; Salomon et al., 2014; Fig. 5.7) and Isola Sacra (Keay, Parcak and Strutt, 2014; (Fig. 5.9) and the palaeomeander of Fiume Morto at Ostia (Salomon et al., 2016) (Fig. 5.8); and finally, the progression of the coastline from Roman times (Arnoldus-Huyzendveld, 2005; Germoni et al., 2011; Fig. 5.10). However, the full potential of these historical interpretations (regardless of the methodological approach used to produce them) comes from their integration within a GIS environment: on the one hand, this reveals the extent of the research gaps that remain to be clarified; on the other hand, it makes it possible to visualize and 
analyse the extent, temporal rhythm and intensity of the transformations that occurred in the Tiber throughout antiquity.

Equally important, the topography of the lower Tiber valley has changed much since antiquity. However, digital modelling can help to recreate this ancient topography as a means to understand the changing relationships between river and port system, i.e. by adding elements of the landscape existing in the past or removing modern landmarks in digital elevation and terrain models. Known elements of transformation are the modern roads and highways, the drainage of the stagni di Ostia and Maccarese (Amenduni, 1884), the cutting of the meanders of Spinacetto (Aguilera Martín, 2012) and Fiume Morto (Salomon et al., 2016), the increases of the ground floor level in the area of Ponte Galeria (Morelli et al., 2011) and Magliana (Catalli, Coletti and ArnoldusHuyzendveld, 1995), the filling of the palude di Campo Merlo, still visible in sixteenth- and seventeenth-century maps (e.g. Carta della Campagna Romana (Della Volpaia and Ashby, 1914) and in the map by Cornelio Meijer, 1685), and the construction of the dykes along the Tiber between Rome and the river mouths to prevent flooding events (Arnoldus-Huyzendveld, 2014: 86). Using techniques of digital topographic modelling within GIS environments, ${ }^{8}$ these transformations were incorporated into the digital terrain model (DTM) ${ }^{9}$ of the Tiber valley. The result is that the creation of three historical digital terrain models (HDTMs) in the three periods under study emphasizes the temporality and spatiality of the changes in the region in antiquity. In period 1 (Fig. 6A), it shows the course's deviation at Campo Marzio, near Santa Passera, around Magliana, Fiera di Roma and the meander at Fiume Morto; in period 2 (Fig. 6B), the system incorporates the Canale di Fiumicino and Canale Traverso, as well as the infrastructures of the Claudian phase at Portus (e.g. the Darsena); and finally, in periods 3 to 5 (Fig. 6C), it includes the Hexagonal Basin, the Canale Romano and the Canale di Isola Sacra within the network.

Creating these models fulfils several goals. Firstly, they constitute powerful means of visualizing the transformations in both river and valley in antiquity, which contribute to the discussion about how these transformations affected the organization of Rome's port system. Secondly, they highlight the vast efforts and means invested by Rome to transform and adapt such extensive areas of the Campagna to the needs of Rome in antiquity. Lastly, they allow us to analyse the territorial and landscape dimension of Rome's port system from a holistic perspective and through an integrated approach to the material evidence

8 This process of topographic modelling was divided into two steps: first, removing the dykes surrounding the Tiber, a hindrance to visibility from the river, and the modern infrastructures (i.e. highways and roads); and second, transferring the modified topography of the river's surroundings into its historical location. This modelling was done using a combination of GIS software including ESRI ArcGIS, QGIS, SAGA GIS, GRASS and WhiteBox.

9 This model combined data from the TIN Italy raster data set (Tarquini et al., 2012) and the LiDAR-based DEM of the Ministero dell'ambiente e della tutela del territorio e del mare (2013). It was used in all the figures included in this research paper. 


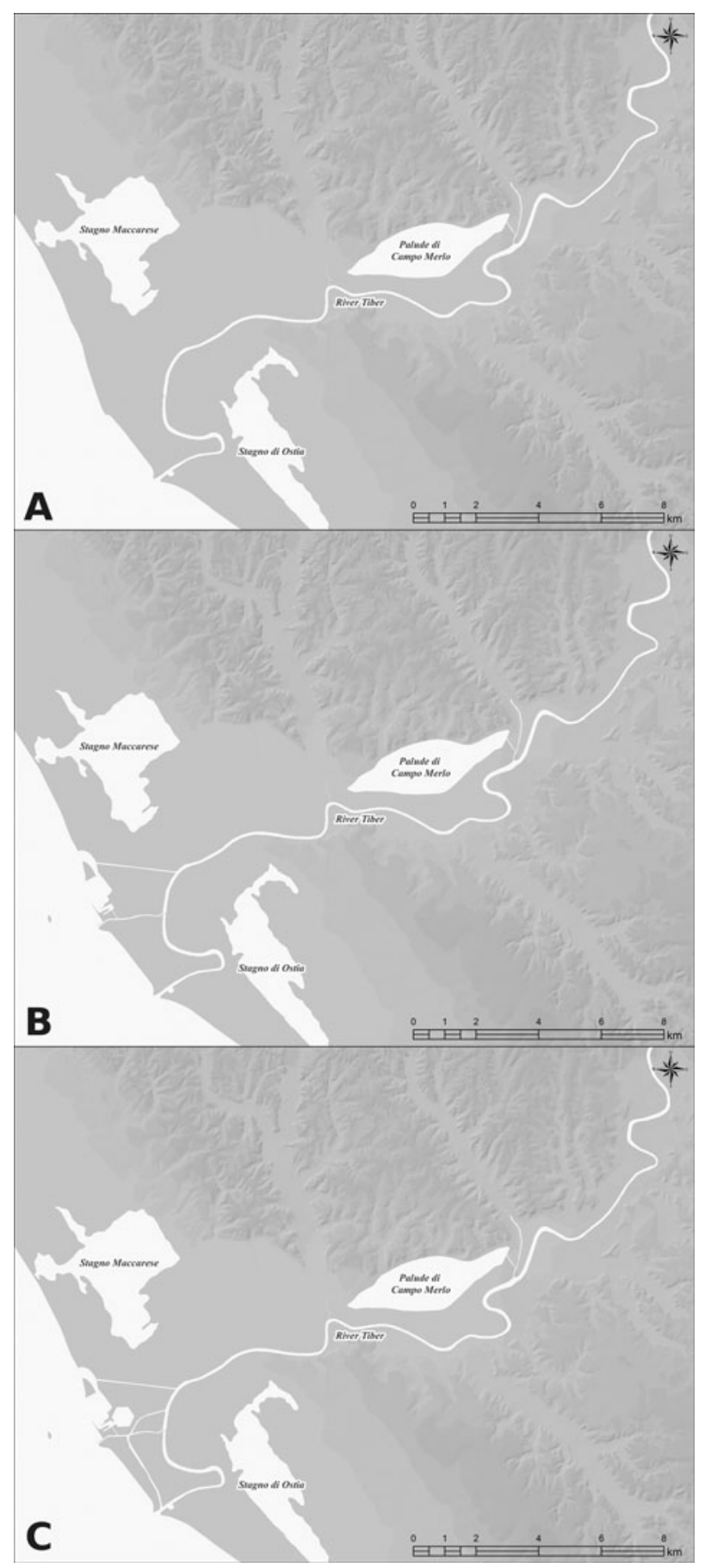

Fig. 6. (A) Reconstructed course of the Tiber during period 1; (B) reconstructed course of the Tiber and its associated canals in period 2 (i.e. the Canale Settentrionale and the Fossa Traiana); (C) reconstructed course of the Tiber and its associated canals in periods 3 to 5 (i.e. the Canale di Isola Sacra, the Canale Romano and the Hexagonal Basin) (Moreno Escobar). 
by means of spatial analysis. The latter has important consequences for understanding the system, as it permits the exploration of organizational aspects of the system not considered by previous research, like the organization of the river traffic, the possible existence of a signalling system to regulate river navigation, and the definition of the system's capacity of transport, which may afford interesting insights into the development of Rome's port system in Imperial times.

\section{UNDERSTANDING THE PORT SYSTEM (I): THE ORGANIZATION OF THE TRAFFIC}

In its natural conditions, the Tiber offered a limited capacity for transport and traffic, determined by the characteristics of its course and the variability of its flow (Le Gall, 2005: 14-15, fig. 5; 79). The creation of port facilities in Rome, Ostia and Portus, as well as the construction of canals, must have partially improved the capacity of the system for transport and storage. In terms of storage, previous work considering the area dedicated to horrea in Portus and Ostia identified a clear trend towards the increase of their storage capacity between the first and second centuries AD (Keay and Millett, 2005b: 302-3, table 9.1). However, the extent to which the system's transport capacity was actually expanded after its numerous improvements remains unclear.

Previous studies have offered partial assessments of the number of boats that could potentially moor at Portus (Boetto, 2010; Wilson, Schörle and Rice, 2012), the number of boats required for the Annona (Tchernia, 2000), and (more generally) of the organization of the river traffic along the Tiber (Malmberg, 2015). This last study is particularly interesting, since it proposes a hypothesis with potential implications for the definition of the system's transport capacity: the existence of three lanes for boat circulation along the Tiber, two on the river margins for towing the boats up to Rome, and a central lane for their return to Ostia and Portus (Fig. 7). This hypothesis remained, nonetheless, unsubstantiated against the material evidence (e.g. for the size of boats travelling along the Tiber) or the geographical context of the Tiber (e.g. the width of the river course), and thus its validity is still unconfirmed. However, this is an aspect of Rome's port system with special relevance for understanding its capacity for transport, since (contrary to its apparently limited significance) the number of potential lanes of circulation in the Tiber may clearly have influenced the amount of goods that could be moved along the river at any one time. As such, it requires careful examination and testing.

Considering previous discussions about the changes of the river course and the valley's topography, the use of the different HDTMs (i.e. representing these changes in the periods under study) in combination with techniques of spatial analysis and computer simulations permits us to test Malmberg's hypothesis through several experiments. These rely on the creation of simple models of 


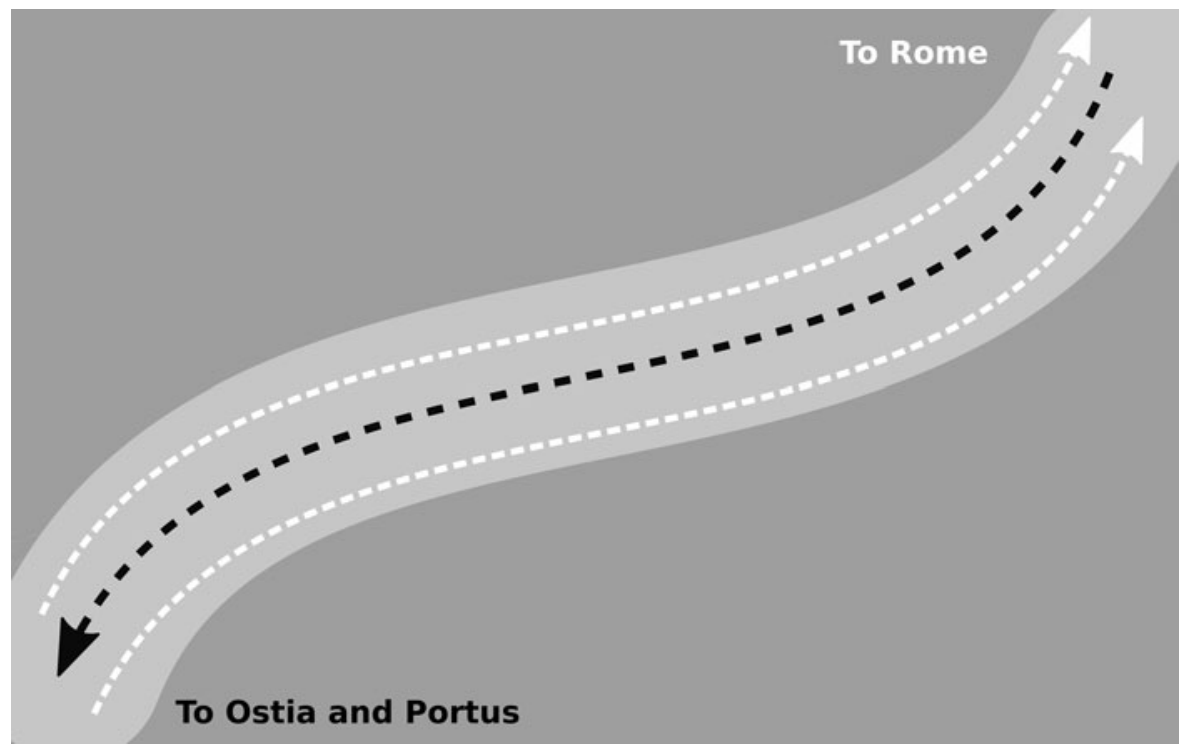

Fig. 7. Model of organization of the river traffic according to Malmberg (2015) (Moreno Escobar after Malmberg, 2015).

navigation along the Tiber within a GIS environment that seeks to estimate the space required by river boats to navigate the Tiber (i.e. the minimum width of the traffic lanes in the river) in each of the periods studied. In this sense, the width of the river along its course between Rome and the river mouths, and the dimensions of the river boats used in Roman times were factors identified as having a major influence on the organization of river navigation, leaving the consideration of other factors for future modelling iterations. ${ }^{10}$

These experiments assumed navigational conditions that ensured the safety of the vessels and their cargoes ${ }^{11}$ and considered the dimensions of the river boats used in river transports, more specifically the Fiumicino 2 (Scrinari, 1979; reinterpreted by Boetto, 2010), a vessel interpreted as navis caudicaria ${ }^{12}$ measuring $6.27 \mathrm{~m}$ of maximum beam (Boetto, 2010: 118). Under these conditions, each of the river lanes must have been (at least) $25.27 \mathrm{~m}$ wide to guarantee the smooth navigation of the boats along the Tiber, whereas all three

10 For example, the seasonal variability of the water flow along the course (Le Gall, 2005: 14-15, fig. 5), the variable depth of the river bed across and along the course, the varying speed of the water flow in different areas within meanders, and the changes to the Tiber's water flow after the deviation of one of its tributaries (the river Val de Chiana) into the river Arno around 1780 (Bersani and Bencivenga, 2001: 27).

11 The formula used to calculate the required space for navigation is: space for manoeuvre (per side) $=$ boat's width $\times 1.5$. Thanks to Dr Felipe Cerezo Andreu (University of Cádiz, Spain) for his help and explanations concerning boats and sailing in antiquity.

12 A type of river boat very commonly used in the lower Tiber (Le Gall, 2005: 275-83). 
lanes would have required a minimum width of $75.81 \mathrm{~m}$ for the entire river course between Rome and the river mouths.

Comparing these estimates with the characteristics of the reconstructed course on the Tiber in the periods under study reveals the difficulty of applying Malmberg's hypothesis as a strategy for organizing river traffic in antiquity, due to the general alternation of stretches where this hypothesis would be applicable or not (Fig. 8A-C): the meeting of three-lane and two-lane stretches (and vice versa) would have generated numerous areas of potential congestion (as many as 27 such locations just in period 1, when the port system was at its least complex), where additional traffic regulation would have been required to facilitate smooth transitions between them both. As a consequence, this alternation along the Tiber would have added extra layers of complexity to the organization and management of river traffic.

The further developments of Rome's port system in period 2 (Fig. 8B) and periods 3 to 5 (Fig. 8C) further emphasize the difficulty of applying Malmberg's model of river circulation: the width of the canals excavated under Claudius (Canale Traverso, Canale Settentrionale and Fossa Traiana) and Trajan (Canale Romano) ranged between 20 and $35 \mathrm{~m}$ in the case of the Canale Settentrionale (Keay, Millett and Strutt, 2005a: 135) and $35 \mathrm{~m}$ in the case of the Canale Romano (Keay and Millett, 2005a: 288), which is insufficient space to host multiple lanes of river traffic. In this regard, the Canale di Isola Sacra presents an unusual scenario, given the changes in the width of its course, from $c .90 \mathrm{~m}$ at its northern end to $c .20 \mathrm{~m}$ at its southern end (Keay, 2012: 49), thus presenting a greater challenge not only for implementing this strategy for river traffic, but for any form of traffic regulation and organization. As a result, it is clear that none of the canals expanding Rome's port system from period 2 could hold three lanes of river traffic.

In conclusion, both the results of the experiments and the characteristics of the canals provide sufficient evidence to suggest that the organization of river traffic cannot have followed the structure proposed by Malmberg, but must have followed some other strategy. In this light, the existence of two parallel lanes of circulation (one upriver and one downriver) in the main river course must have coexisted with one-way movements of boats in the artificial canals, which may have involved potential changes of direction regulated through signalling or some other means of communication and regulation.

\section{UNDERSTANDING THE PORT SYSTEM (II): THE CAPACITY FOR TRANSPORT}

Another question intimately related to the organization of the port system is the relationship between its expansion and the potential increase in the capacity for transport on the Tiber in antiquity. As mentioned before, this would have been subject to factors such as the natural characteristics of the river, but most importantly the capacity of the vessels used for transporting goods along the 


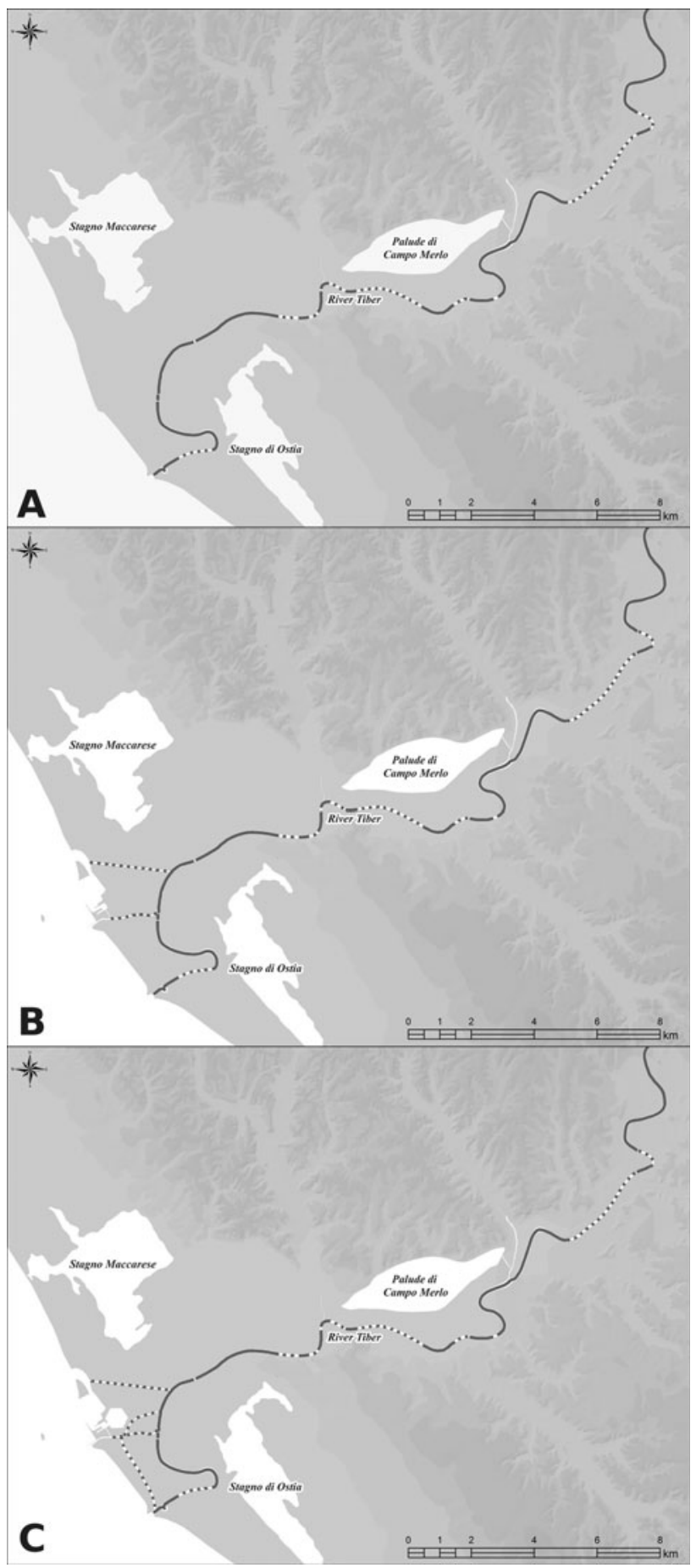

Fig. 8. Application of Malmberg's hypothesis to the modelled course of the Tiber in period 1 (A), period 2 (B) and periods 3 to $5(\mathrm{C})$. The continuous lines represent the sections where this hypothesis is possible, and the dotted lines define the sections where it is not possible (Moreno Escobar). 
Table 3. Length of the different waterways composing Rome's port system across the periods under study (Moreno Escobar).

\begin{tabular}{|c|c|c|c|c|c|}
\hline \multicolumn{2}{|l|}{ Period 1} & \multicolumn{2}{|l|}{ Period 2} & \multicolumn{2}{|l|}{ Periods $3-5$} \\
\hline \multirow[t]{5}{*}{ River Tiber } & 35.5 & River Tiber & 35.5 & River Tiber & 35.5 \\
\hline & & Fossa Traiana & 1.7 & Fossa Traiana & 1.7 \\
\hline & & Canale Settentrionale & 2.7 & Canale Settentrionale & 2.7 \\
\hline & & & & Canale Romano & 1.5 \\
\hline & & & & Canale di Isola Sacra & 2.6 \\
\hline Total & 35.5 & & 39.9 & & 43.9 \\
\hline
\end{tabular}

Table 4. Length of waterways and related maximum capacity of transport of the Tiber in each period. NC is naves caudicariae. The transported tonnage is based on the estimated capacity of the Fiumicino 2 in Boetto (2010: 118).

\begin{tabular}{lccc}
\hline Period & Course length $(\mathrm{m})$ & Total of NC (per lane) & Transported tonnage (one way) \\
\hline Period 1 & 35,510 & 910 boats & 63,700 \\
Period 2 & 39,881 & 1,023 boats & 71,610 \\
Periods 3-5 & 43,941 & 1,127 boats & 78,820 \\
\hline
\end{tabular}

river. However, it is possible to shed more light on this by focusing on the changes in length of the river course and canals ${ }^{13}$ (Table 3), as well as the changes in the estimated area required for safe manoeuvrability of the naves candicariae (calculated in the previous section), under the assumption that they were towed individually, and not attached to each other in convoys. The creation of models exploring the development of the port system in each of the periods under study provides interesting estimates for the maximum number of boats that could have been moving simultaneously in each of the river lanes at any one time (Table 4). These, in turn, can easily be translated into tonnages of goods that could potentially have been moved at any one time on the Tiber. However, it is important to highlight that these estimates should not be taken at face value, since the system's capacity for transport must have differed depending on the navigation conditions of the river itself, the supply needs of Rome, the type and capacity of the river vessels used for transporting these goods, and how these vessels were arranged to be towed, amongst many other factors. The diversity of the transport capacity that these factors offer emphasizes the nature of the port system as a highly dynamic entity whose functioning adapted to the necessities of Rome's supply seasonally and across periods.

Regardless of this inherent variability of possible requirements and scenarios, these estimates still constitute an important advancement of the comprehension of Rome's port system, since they offer clear indications of the potential for the movement and transport of goods between the different nodes and (more

13 The coordinate system used in these calculations was ETRS 1989 UTM Zone 32N. 
interestingly) of how it increased through time: compared with period 1 , the system's capacity grew 12.48 per cent in period 2 and 23.85 per cent in periods 3 to 5. Interestingly, these increases and estimates consider all kinds of goods supplied to Rome, and as such they represent a clear improvement over previous calculations, which were focused on specific goods, such as the yearly arrival at Rome of 350,000 tonnes of wheat, 23,400 tonnes of olive oil and $3,200,000$ wine amphorae as estimated by Tchernia (2000), and the estimation by Boetto (2006: 421-2) of a proposed fleet of 251 naves caudicariae of medium size (70 tonnes) for transporting these volumes of foodstuffs. However, Rome's supply needs far exceeded merely wheat, olive oil and wine with which to feed the population: other and more varied foodstuffs must have been imported into the city, along with building materials for sustaining Rome's construction activities as well as exotic and luxury goods, amongst others, for which we lack estimates. As a result, by focusing on the spatial characteristics of the port system, the emphasis shifts from specific aspects of the supply or particular goods to the potential capacity for transport and supply to Rome, thus offering a more holistic interpretation of the question of Rome's supply in antiquity.

\section{UNDERSTANDING THE PORT SYSTEM (III): EXPLORING THE SIGNALLING SYSTEM}

The growth of Rome's port systems and the increase in its capacity to cope with Rome's supply needs demanded the construction of new canals connecting Rome, Ostia and Portus, and the redevelopment of port infrastructures. These developments increased the complexity of the system and resulted in the proliferation of potential areas of congestion, such as canal junctions and river meanders. These circumstances were most likely addressed through the creation of a system of visual signalling for regulating the river traffic to ensure the smooth flow of transported goods to Rome. As with many other aspects of Rome's port system, the archaeological and historical evidence attesting the existence and organization of this signalling system is very limited: both the profound transformations and the successive flooding events (Bersani and Bencinega, 2001) in the river valley since antiquity have erased the traces of archaeological structures in the vicinity of the river. However, there are certain elements that point to the interest of Roman authorities in the visual control of the river traffic, such as an inscription (CIL VI 29772) found in Piano delle Due Torri (Macciocca, 2004) whose interpretation suggests the existence of a visual post in the vicinity of the river during the early Imperial period. More interestingly, the integrated analysis of the archaeological evidence at the scale of landscape proposed here may permit the reinterpretation of certain sites known previously on the basis of their connection with Rome's port system.

Computer modelling permits us to explore this signalling system, compensating for the physical transformation of the Tiber valley and the scarcity of material 
evidence: the analysis of the visual characteristics of the area in antiquity would define the location of these signalling positions, potentially located in the areas most clearly visible from the river (i.e. the axis along which goods were moved within the port system). Based on these assumptions, three computer simulations (one per period under study) were designed to combine movement and vision across the ancient topography of the Tiber valley (contained in the HDTMs discussed earlier) as means of defining the most clearly visible locations in the landscape around the Tiber when travelling on a river boat to Rome.

This methodological approach relies on the calculation of individual 'fuzzy viewsheds' 14 from multiple locations along the river route to Rome, since they offer more 'realistic' assessments of vision and visibility by considering the decay in visual acuity that distance and other environmental factors add in (Ogburn, 2006). Specifically, three itineraries were explored (one for each period, to acknowledge both the development of Rome's port system and the changing roles played by Ostia, Portus and the canals across time). Each of these presented the route which a navis caudicaria (similar to Fiumicino 2) might have followed when towed upriver to the Emporium in Rome: ${ }^{15}$ from Ostia in period 1; from Ostia, from the confluence of the Fossa Traiana and the Canale Traverso, and the Canale Settentrionale in period 2; and, in addition, the course along the Canale de Isola Sacra and the Canale Romano in periods 3 to 5 . The sum of all these viewsheds for each itinerary (Fig. 9, for period 1) informs us about the visual structure of the landscape and defines two visual regions in the Tiber valley (one more open from around Ponte Galeria to the sea, and one more limited by the topography towards Rome) which need to be explored separately to prevent the masking of visual dynamics within any of these regions.

The resulting maps provide indications about the potential role of certain locations along the valley, such as the hills to the north of the river plain, but they also inform us of potential biases in the quantification of the clarity of vision: visibility is much greater in areas closer to the river than in areas further away. This effect can be mitigated by combining these cumulative fuzzy viewshed maps with cumulative binary viewshed maps ${ }^{16}$ (Fig. 10 for period 1).

14 Unlike other ways of calculating visibility (Wheatley and Gillings, 2002: 204-9), fuzzy viewsheds acknowledge the increasingly poor quality of vision due to environmental factors (amongst others) (Fisher, 1994), and as such represent an enriched approach to estimating visibility in GIS environments.

15 These fuzzy viewsheds were calculated in ESRI ArcGIS 10.1 through an algorithm based on Ogburn, 2006, and automatized by Rášová, 2014. Observers (2.6 $\mathrm{m}$ in height) were distributed along these itineraries at every $200 \mathrm{~m}$ to identify elements in the landscape at a theoretical height of $2 \mathrm{~m}$, to simulate an individual placed in a light structure for signalling.

16 Adapting the concept of cumulative viewshed (Wheatley and Gillings, 2002: 207-8), individual binary viewsheds were calculated from the individual fuzzy viewsheds to define the areas that were visible or not to each of the observers along the itineraries to Rome. Binary viewsheds were then calculated through map algebra. 


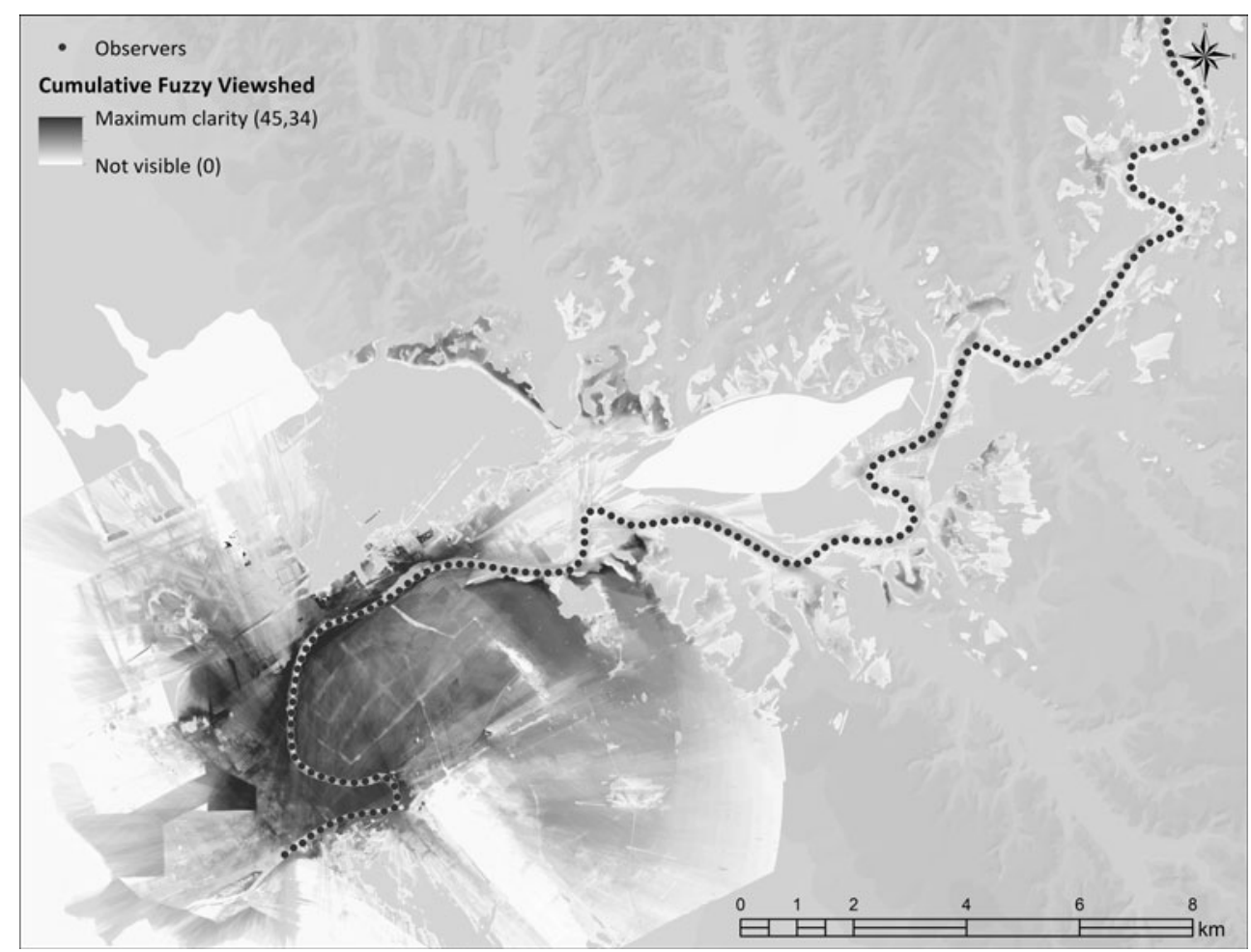

Fig. 9. Map of cumulative fuzzy viewshed for period 1, calculated by adding all individual fuzzy viewsheds through map algebra (Moreno Escobar).

The results of these calculations generate maps of enhanced visibility that delimit the most probable locations for signalling positions in the different periods (Fig. 11 for period 1; Fig. 12 for period 2; Fig. 13 for periods 3-5), and permit us to explore the development of the signalling system in connection with the growth of Rome's port system through time.

The itinerary explored for period 1 (from Ostia to the Emporium in Rome) shows in darker colours the potential location of signalling positions along the Tiber before the construction of Portus (Fig. 11). As mentioned before, it reflects distinctive patterns in the two visual regions in the Tiber valley: more constrained in the upper half of the itinerary to Rome (Fig. 11 right), where the elevations closer to the river and the immediate surroundings of the meanders could represent the most suitable locations for signalling positions; and (in contrast) a more open geography in the lower region (Fig. 11 left) that offers a very limited extent of the highest band of visibility (mainly around the modern Capo di Due Rami), whereas the remaining higher bands of visibility extend over the Tiber's immediate surroundings.

The itineraries explored in period 2 (from Ostia, the confluence of the Canale Traverso and the Fossa Traiana, and the Canale Settentrionale) (Fig. 12) show the varying impact of the construction of Portus in Claudian times in the Tiber valley. 


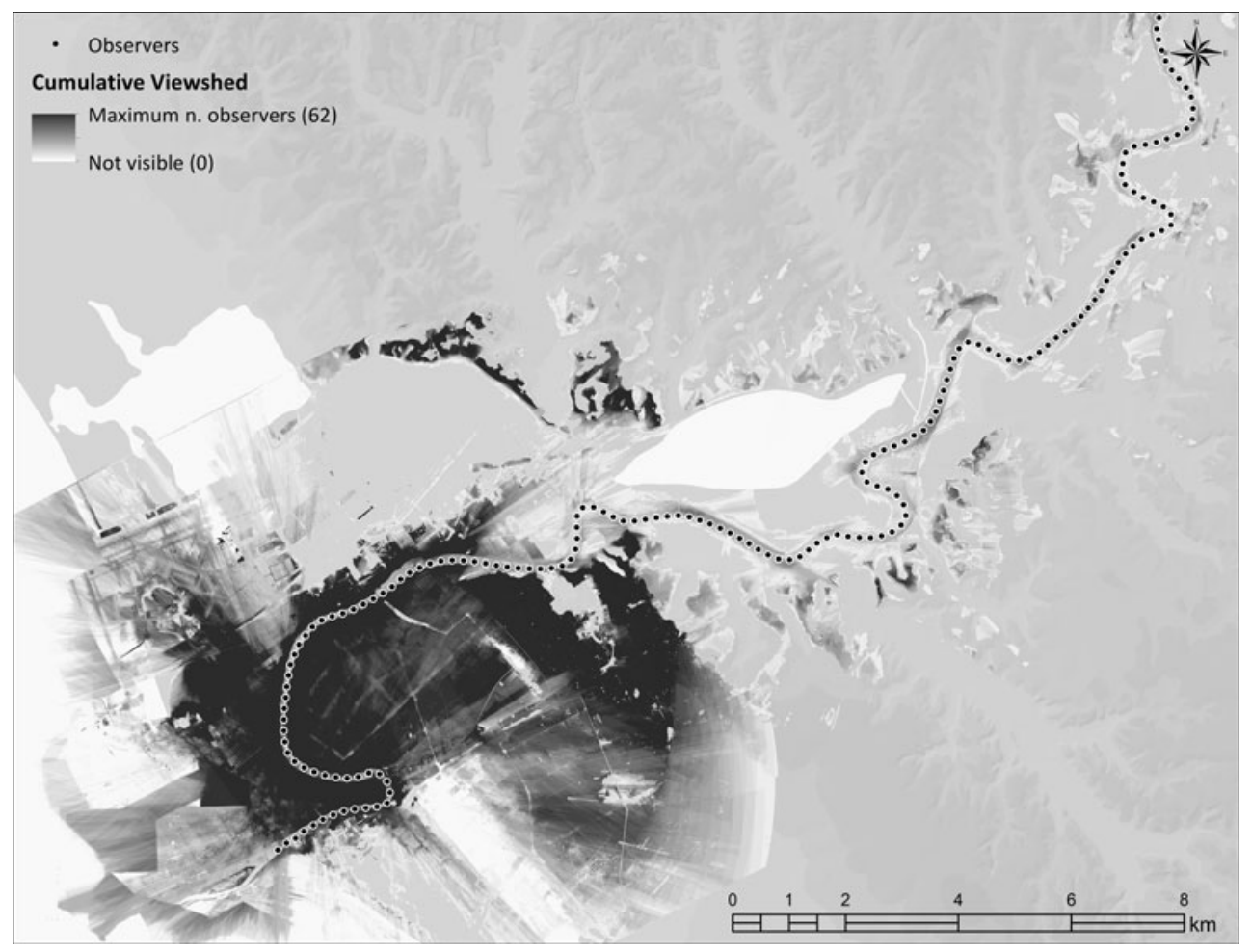

Fig. 10. Map of cumulative binary viewshed for period 1, calculated by adding all individual binary viewsheds through map algebra (Moreno Escobar).
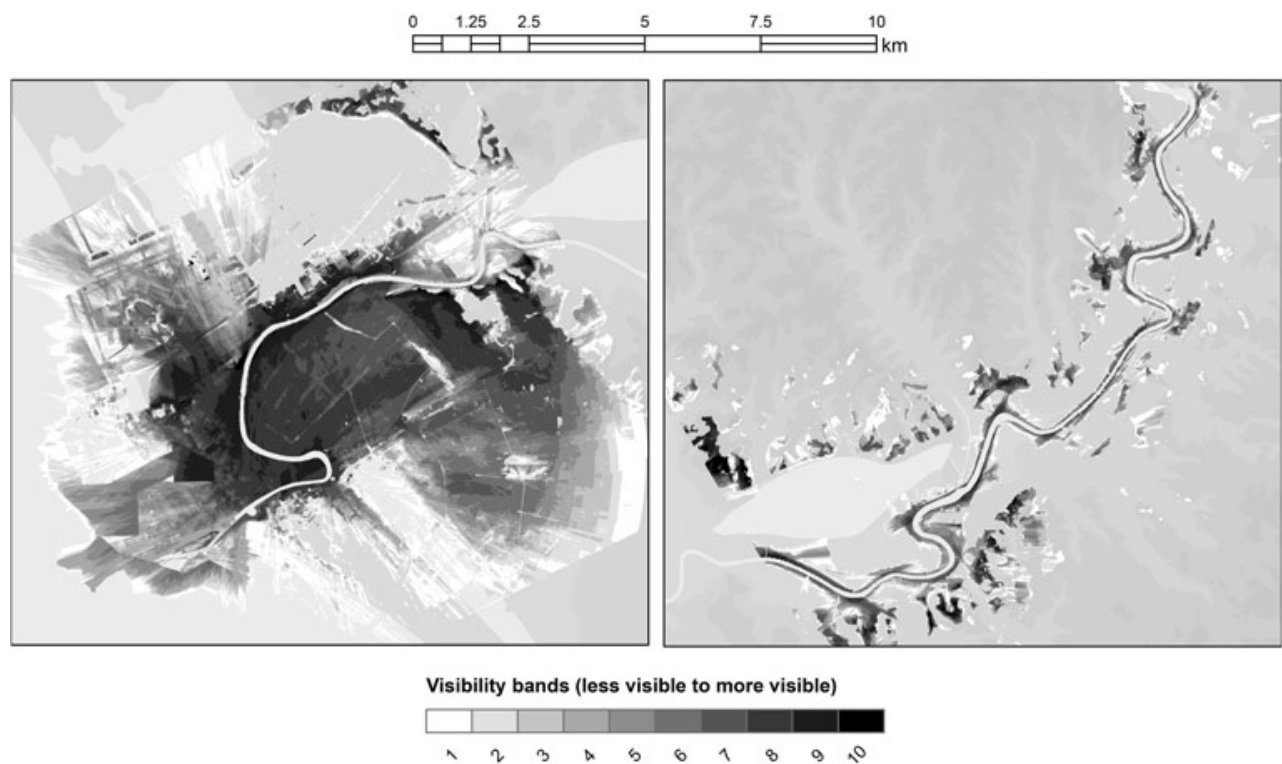

Fig. 11. Map of enhanced visibility for period 1. It represents different degrees of visibility (or visibility bands) ranging from more visible (10, darker shades) to less visible (1, lighter shades) (Moreno Escobar). 


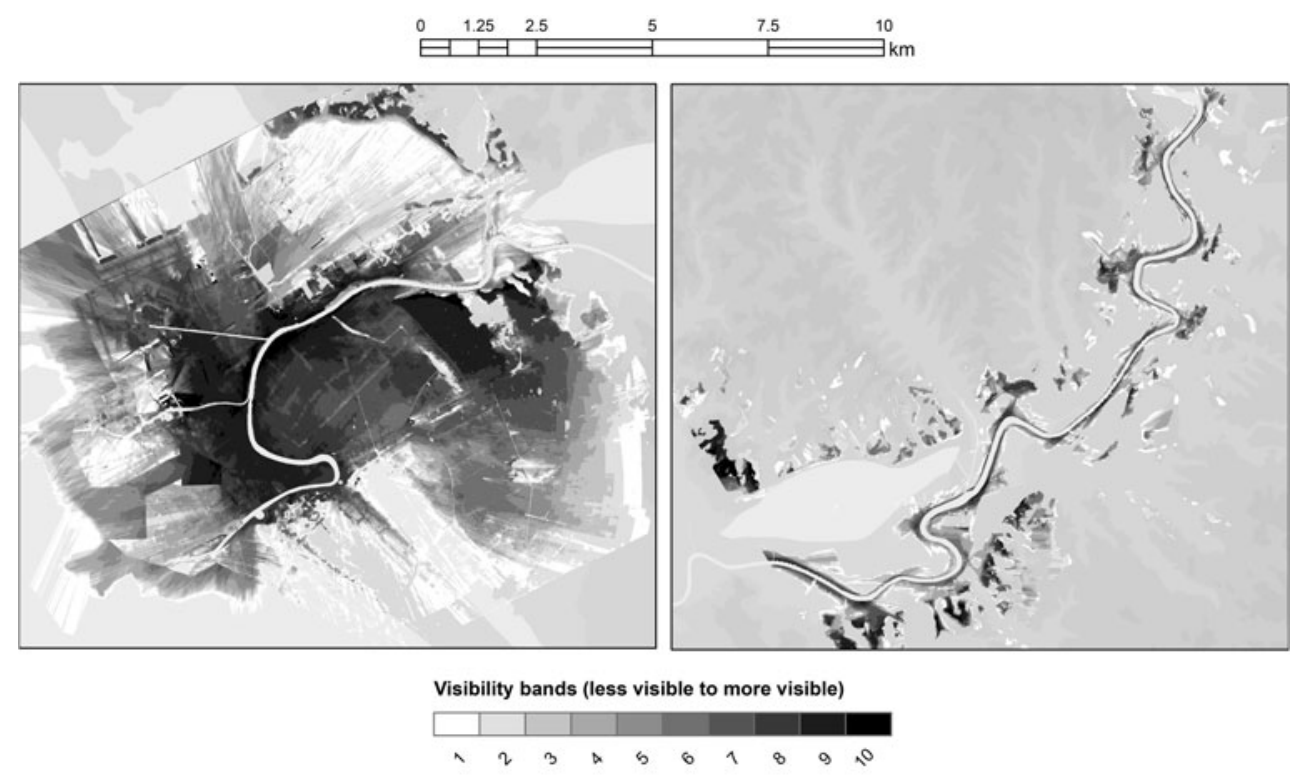

Fig. 12. Map of enhanced visibility for period 2. It represents different degrees of visibility (or visibility bands) ranging from more visible (10, darker shades) to less visible (1, lighter shades) (Moreno Escobar).

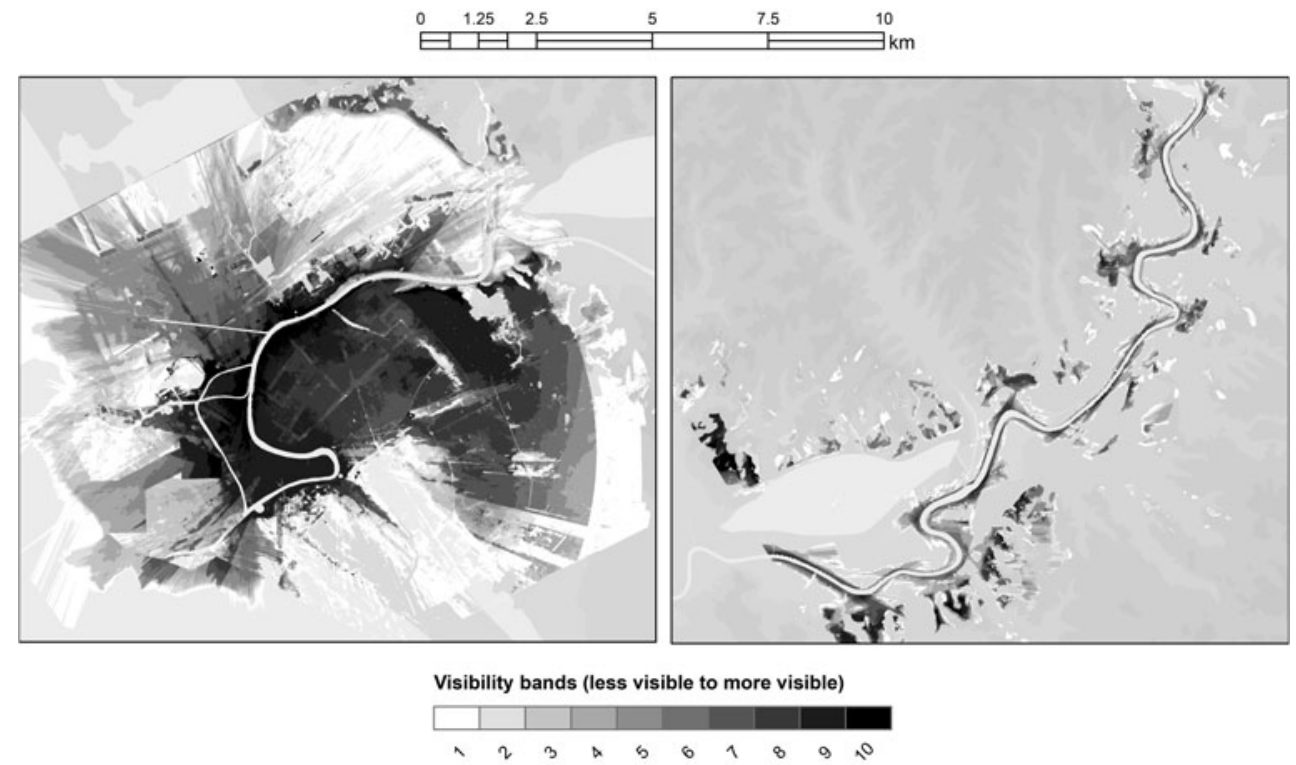

Fig. 13. Map of enhanced visibility for periods 3 to 5. It represents different degrees of visibility (or visibility bands) ranging from more visible (10, darker shades) to less visible (1, lighter shades) (Moreno Escobar). 
Whereas continuity remains the main trait in the upper half of the valley towards Rome (Fig. 12 right), as no significant alterations were introduced in its topography, the lower part of the valley presents important changes (Fig. 12 left): areas of highest visibility are more extensive around the immediate surroundings of the Tiber's course between Fiera di Roma, Capo di Due Rami and its confluence with the Fossa Traiana, and to a lesser extent around the Canale Traverso and the Fossa Traiana. Although the increased visibility of these areas is linked to the higher number of observers distributed in the new canals, it also highlights the importance of this location for potentially controlling and regulating the increase of port activity in this area, which acquired a more crucial role within the lower half of the Tiber valley.

The itineraries explored for periods 3 to 5 (adding the Canale di Isola Sacra and the Canale Romano to the network of period 2) offer similar trends to the ones developed after the expansion of Portus during Trajanic times (Fig. 13). Again, the upper area of the lower Tiber valley (Fig. 13 right) sees no evident changes in the structure and location of visibility in the surroundings of the river Tiber. However, many changes occurred in the visual structure of the lower part of the study area (Fig. 13 left), as a consequence of the deep transformations associated with the expansion of Portus: there is a significant increase in the visual importance of the area around Portus, as the growing extent of the most visible locations demonstrates, highlighted by the highestvisibility band, extending much further into the surroundings of the Tiber between Fiera di Roma and Isola Sacra. More changes developed in the vicinity of the Canale Romano and the upper half of the Fossa Traiana, areas presenting higher degrees of visual prominence, as well as in the vicinity of the intersection of the Canale Traverso and the Fossa Traiana, whose visual prominence decreases as a consequence of the urban and architectural developments on both sides of the canal during Trajanic times.

Comparing the delimitations of the areas of highest visibility and the areas of potential congestion on river traffic across time ${ }^{17}$ also provides interesting insights. Firstly, it becomes clear that both the construction and expansion of Portus and the excavation of the canals connecting it with Ostia and Rome substantially increased the transport capacity of the port system and improved the conditions for transhipment at the river mouths. But they also altered the organization of the river traffic by increasing the number of congestion areas at the intersections of canals and the river course across time (Fig. 14). The construction and development of Portus increased the complexity of movement in the area, making the development of the signalling system a requirement for the proper functioning of the port system and for ensuring the smooth flow of goods coming to Rome from Portus and Ostia. More interestingly, these calculations highlight the potential importance of two sites located precisely in the areas of highest visibility: the Early River Port (APT Id 398) (Keay and

17 Previously discussed by Keay, 2012: 49-52 and fig. 2.9. 


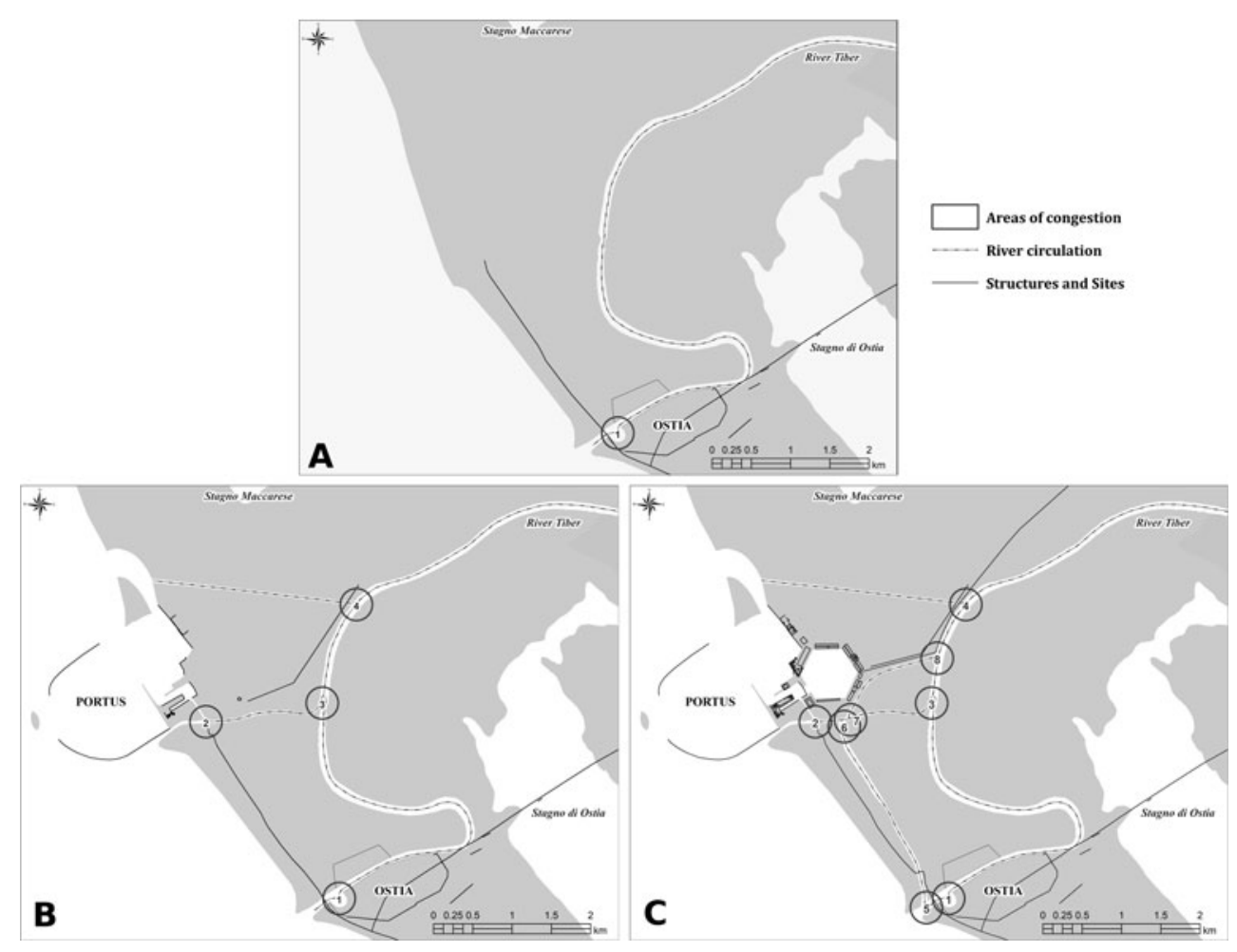

Fig. 14. Possible areas of congestion for river traffic around Portus and Ostia in period 1 (A), period 2 (B) and periods 3 to $5(\mathrm{C})$ : 1, harbour at Ostia; 2, junction between Canale Traverso and Fossa Traiana; 3. junction at Capo Due Rami; 4, junction between Canale Settentrionale and river Tiber; 5, junction between Canale di Isola Sacra and Ostia; 6, junction between Canale di Isola Sacra and Fossa Traiana; 7. junction between Canale Romano and Fossa Traiana; 8, junction between Canale Romano and river Tiber (Moreno Escobar).

Millett, 2005b: 281) in period 2 and the River Port (APT Id 399) (Keay, Millett and Strutt, 2005a: 150-6) from periods 3 to 5. The lack of information about these sites (known only through archaeological evidence from surface and geophysical surveys) impedes us from formulating any interpretation in connection with the port system. The possibility of their role in regulating the river traffic (given their strategic location) remains hypothetical until further research can substantiate them.

\section{REASSESSING ROME'S PORT SYSTEM}

This paper has sought to emphasize the advantages of data integration and of holistic approaches to archaeological research for improving and widening our understanding of complex systems and their development through time. Applying these perspectives to the port system of Imperial Rome has 
contributed to the re-evaluation of previous hypotheses and has shed new light upon several aspects of its internal organization, opening new paths of research.

One example of the benefits of data integration and analysis has been the reconstruction of the river course during Imperial times using historical maps, geoarchaeological studies, archaeological analyses and GIS-based modelling. The resulting models permitted us to emphasize the deep transformations that have occurred in the Tiber since antiquity, as well as to explore their extent and rhythms of change at a regional scale. But most importantly, they highlight the scale and impact of the Roman intervention on the river and its surroundings (in less than a century) for ensuring the frictionless supply to Rome and its inhabitants through the construction and expansion of ports and the excavation of canals to connect the maritime ports at Ostia and Portus with Rome.

The creation of these models permitted us to explore the organization of the river traffic and the impact of the port system's enlargement across time though the combination of spatial analysis and the study of river boats found at Portus: firstly, by defining the feasibility of two lanes of river traffic for navigation between Rome, Portus and Ostia; and secondly, by proposing explicit estimates of the increase in the river's transport capacity in the different periods. Lastly, they have also highlighted the increasing complexity of the system, which most likely required the creation of a system of signalling along the Tiber and whose modelling, based on visibility along the river, has underscored the potential role of the (poorly understood) River Port and Early River Port near Portus within the entire system.

Finally, this research has highlighted new paths for future research in the case of Rome's port system: to provide a better understanding of potentially strategic sites, such as the Early River Port and the River Port, and to achieve better archaeological knowledge of the most visible areas since they might still hold clues about the organization of river traffic and the port system. But also, this research might be linked to other aspects of Rome's port system, such as the exploration of the potential correlation between the increase of the system's transport capacity and its storage capacity through time (Rickman, 2002; Keay and Millett, 2005b: 300-3). In short, the tools and the approach for unravelling the complexities of the port system of Imperial Rome are ready. Now it is time to use them.

Address for correspondence:

Dr Maria del Carmen Moreno Escobar

Department of Archaeology, University of Southampton, University Road, Southampton SO17 1BJ, United Kingdom

Department of Archaeology, Durham University, South Road, Durham DH1 3LE, United Kingdom maria.c.moreno-escobar@durham.ac.uk 


\section{REFERENCES}

Aguilera Martín, A. (2012) La sirga en el Tíber en época romana. In S. Keay (ed.), Rome, Portus and the Mediterranean: 105-26. London, The British School at Rome and the Soprintendenza Speciale per i Beni Archeologici di Roma, sede di Ostia.

Amenduni, G. (1884) Sulle opere di bonificazione della plaga litoranea dell'Agro Romano che comprende le paludi e gli stagni di Ostia, Porto, Maccarese e delle terre vallive di Stracciacappa, Baccano, Pantano e Lago dei Tartari. Rome, Botta.

Arnoldus-Huyzendveld, A. (2005) The natural environment of the Agro Portuense. In S. Keay, M. Millett, L. Paroli and K. Strutt (eds), Portus, an Archaeological Survey of the Port of Imperial Rome: 14-29. Rome, British School at Rome.

Arnoldus-Huyzendveld, A. (2014) Le dinamiche evolutive dell'ambiente costiero e del Tevere. In L. Caravaggi and C. Morelli (eds), Paesaggi dell'archeologia invisibile: il caso del distretto Portuense=Invisible Archaeology Landscapes: The Context of Portuense District: 72-89. Macerata, Quodlibet.

Ascani, F., Bozzano, F., Buccellato, A., Del Monte, M., Matteucci, R. and Vergari, F. (2008) Evoluzione del paesaggio e antiche vie di drenaggio nell'area de "Il Castellaccio" (Roma) da indagini geologiche, geomorfologiche e archeologiche. Geologia Romana 41: 93-116.

Bersani, P. and Bencivenga, M. (2001) Le piene del Tevere a Roma dal V secolo a.C. all'anno 2000. Rome, Servizio Idrografico e Mareografico Nazionale.

Boetto, G. (2006) Les navires de Fiumicino (Italie): architecture, matériaux, types et fonctions; contribution à l'étude du système portuaire de Rome à l'époque impériale. Aix-Marseille 1 and Université de Provence, Ph.D. thesis.

Boetto, G. (2010) Le port vu de la mer: l'apport de l'archéologie navale à l'étude des ports antiques. Bollettino di Archeologia Online - Volume speciale: 112-28.

Boetto, G. (2016) Portus, Ostia and Rome: a transport zone in the maritime/land interface. In K. Höghammar, B. Alroth and A. Lindhagen (eds), Ancient Ports: The Geography of Connections: 269-90. Uppsala, Uppsala Universitet.

Brughmans, T., Hanson, J.W., Mandich, M.J., Romanowska, I., Rubio-Campillo, X., Collins-Elliott, S., Crawford, K., Daems, D., de Haas, T., Kelly, P., Moreno Escobar, M.C., Paliou, E. and Ritondale, M. (2019) Formal modelling approaches to complexity science in Roman studies: a manifesto. Theoretical Roman Archaeology Journal 2: 1-19.

Buzón Alarcón, M., Carrillo Díaz-Pinés, J.R., Fábrega García, T., Mendoza Álvarez, D., Moreno Escobar, M.C., Sánchez Romero, M., Vargas Vázquez, S. and Hidalgo Prieto, R. (2016) Apéndice. La base de datos "Villas romanas de la Bética". In R. Hidalgo Prieto (ed.), Las villas romanas de la Bética: 781-96. Seville, Servicio de Publicaciones de la Universidad de Sevilla.

Carayon, N. (2018) Evaluating the maritime potential of Mediterranean ports and harbour systems in the Roman period. PortusLimen: Rome's Mediterranean Ports. Workshop 4-25th and 26th January 2018, Rome. https:/www.bsr.ac.uk/site2014/wp-content/uploads/2018/01/BSRWorkshop-2018-Final-Abstracts-v7.pdf (accessed 26 March 2019).

Catalli, F., Coletti, C.M. and Arnoldus-Huyzendveld, A. (1995) Acquisizioni archeologiche e paleoambientali nell'area della Magliana. Archeologia Laziale 12: 333-40.

Della Volpaia, E. and Ashby, T. (1914) La campagna romana al tempo di Paolo III: mappa della Campagna Romana del 1547 di Eufrosino della Volpaia riprodotta dall'unico esemplare esistente nella Biblioteca Vaticana. Piante maggiori di Roma dei secoli sedicesimo e decimosettimo. Rome, Danesi.

Fisher, P. (1994) Probable and fuzzy models of the viewshed operation. In M.F. Worboys (ed.), Innovations in GIS: Selected Papers from the First National Conference on GIS Research UK: 161-75. London, Taylor and Francis. 
Germoni, P., Millett, M., Keay, S. and Strutt, K. (2011) The Isola Sacra: reconstructing the Roman landscape. In S. Keay and L. Paroli (eds), Portus and Its Hinterland: Recent Archaeological Research: 231-60. London, British School at Rome.

Hidalgo Prieto, R. (ed.) (2016) Las villas romanas de la Bética. Seville: Servicio de Publicaciones de la Universidad de Sevilla.

Keay, S. (2012) The port system of Imperial Rome. In S. Keay (ed.), Rome, Portus and the Mediterranean: 33-68. London, The British School at Rome and the Soprintendenza Speciale per i Beni Archeologici di Roma, sede di Ostia.

Keay, S. (2016) Portus in its Mediterranean context. In K. Höghammar, B. Alroth and A. Lindhagen (eds), Ancient Ports: The Geography of Connections: 292-322. Uppsala, Uppsala Universitet.

Keay, S. and Millett, M. (2005a) Integration and discussion. In S. Keay, M. Millett, L. Paroli and K. Strutt (eds), Portus, an Archaeological Survey of the Port of Imperial Rome: 267-96. Rome, British School at Rome.

Keay, S. and Millett, M. (2005b) Portus in context. In S. Keay, M. Millett, L. Paroli and K. Strutt (eds), Portus, an Archaeological Survey of the Port of Imperial Rome: 297-314. Rome, British School at Rome.

Keay, S., Millett, M. and Strutt, K. (2005a) The survey results. In S. Keay, M. Millett, L. Paroli and K. Strutt (eds), Portus, an Archaeological Survey of the Port of Imperial Rome: 71-172. Rome, British School at Rome.

Keay, S., Millett, M., Paroli, L. and Strutt, K. (2005b) (eds) Portus, an Archaeological Survey of the Port of Imperial Rome. Rome, British School at Rome.

Keay, S., Parcak, S.H. and Strutt, K.D. (2014) High resolution space and ground-based remote sensing and implications for landscape archaeology: the case from Portus, Italy. Journal of Archaeological Science 52: 277-92.

Keay, S. and Paroli, L. (2011) (eds) Portus and Its Hinterland. London, The British School at Rome and the Soprintendenza Speciale per i Beni Archeologici di Roma, sede di Ostia.

Le Gall, J. (2005) Il Tevere, fiume di Roma nell'antichità. Rome, Quasar.

Leonardi, R., Pracchia, S., Buonaguro, S., Laudato, M. and Saviane, N. (2010) Sondaggi lungo la tratta T2: caratteri ambientali e aspetti topografici del Campo Marzio in epoca romana. In R. Egidi, F. Filippi and S. Martone (eds), Archeologia e infrastrutture. Il tracciato fondamentale della Linea $\mathrm{C}$ della Metropolitana di Roma: prime indagini archeologiche: Bollettino d'arte volume speciale: 82-93. Florence, Leo S. Olschki.

Lo Cascio, E. (2018) The population. In C. Holleran and A. Claridge (eds), A Companion to the City of Rome: 139-53. Hoboken (NJ)/Chichester, Wiley Blackwell.

López-Mondéjar, L. (2019) De íberos a romanos. Poblamiento y territorio en el Sureste de la Península Ibérica (siglos IV a.C. - III d.C.). Oxford, BAR Publishing.

Macciocca, M. (2004) Cocceiani et Titiani horti. In A. La Regina (ed.), Lexicon Topographicum Urbis Romae: Suburbium: 124. Rome, Quasar.

Malmberg, S. (2015) 'Ships are seen gliding swiftly along the sacred Tiber': the river as an artery of urban movement and development. In I. Östenberg, S. Malmberg and J. Bjørnebye (eds), The Moving City: Processions, Passages and Promenades in Ancient Rome: 187-201. London/ New Delhi/New York/Sydney, Bloomsbury.

Meiggs, R. (1973) Roman Ostia. Oxford, Oxford University Press.

Meijer, C. (1685) L'arte di restituire a Roma la tralasciata navigatione del suo Tevere. Rome, Stamperia del Lazzari Varese.

Mellace, V.S., Rosa, C., Matteucci, R. and Sebastiani, R. (2011) Le indagini geoarcheologiche nel quadrante sud-ovest di Roma: l'Italgas e gli ex Mercati Generali. In A. Gallone and S. Zottis (eds), L'archeologia con gli occhi di Silvia. Catania, Prampolini.

Ministero dell'ambiente e della tutela del territorio e del mare (2013) DTM based on LiDAR for the regione Lazio. 
Mocchegiani Carpano, C. (1981) Indagine archeologiche nel Tevere. Archeologia Laziale 4: 142-59. Mocchegiani Carpano, C. (1995) Emporium. In E.M. Steinby (ed.), Lexicon Topographicum Urbis Romae II. D-G: 221-3. Rome, Quasar.

Morelli, C., Carbonara, A., Forte, V., Grossi, M.C. and Arnoldus-Huyzendveld, A. (2011) La topografia romana dell'Agro Portuense alla luce delle nuove indagini. In S. Keay and L. Paroli (eds), Portus and Its Hinterland: 261-86. London, The British School at Rome and the Soprintendenza Speciale per i Beni Archeologici di Roma, sede di Ostia.

Moreno Escobar, M.C. (2020) Linking seascapes and landscapes: the case of Tarraco (Tarragona, Spain) during the Roman Empire. In A. Cristilli, A. Gonfloni and F. Stok (eds), Experiencing the Landscape in Antiquity. I Convegno Internazionale di Antichità - Università degli Studi di Roma 'Tor Vergata': 209-16. Oxford, British Archaeological Reports.

Moreno Escobar, M.C. and García Sanjuán, L. (2013) Sistematización e informatización del inventario de yacimientos arqueológicos de Tierras de Antequera: la base de datos ARCA. Menga. Revista de Prehistoria de Andalucía 4: 217-34.

Moreno Escobar, M.C., Ojeda Rivera, J.F. and García Sanjuán, L. (2020) Effects of Roman rule on the settlement geography of southern Iberia: a GIS-approach. Oxford Journal of Archaeology 39: 189-212.

Moreno Escobar, M.C. and Wheatley, D. (2016) De columnas, necrópolis y puntos: análisis espacial de las villas romanas y asentamientos rurales de Andalucía. In R. Hidalgo Prieto (ed.), Las villas romanas de la Bética: 39-67. Seville, Servicio de Publicaciones de la Universidad de Sevilla.

Ogburn, D. (2006) Assessing the level of visibility of cultural objects in past landscapes. Journal of Archaeological Science 33: 405-13.

Pavolini, C. (2006) Ostia. Guide archeologiche Laterza. Rome/Bari, Laterza.

Pensabene, P. and Domingo, J.Á. (2017) Il cantiere, l'approvvigionamento dei marmi, il trasporto e i costi dei grandi monoliti in granito del Foro e in sienite. Rendiconti: Atti della Pontificia Accademia Romana di Archeologia 89: 523-98.

Pensabene, P. and Domingo, J.Á. (2018) Trajano y las canteras de granito del Mons Claudianus en Egipto: el transporte y puesta en obra de los grandes fustes monoliticos del Foro de Trajano. Veleia 35: 1-20.

Rášová, A. (2014) Fuzzy viewshed, probable viewshed, and their use in the analysis of prehistoric monuments placement in Western Slovakia. In J. Huerta Guijarro, S. Schade and C. Granell Canut (eds), Connecting a Digital Europe through Location and Place. Proceedings of the AGILE 2014 International Conference on Geographic Information Science. Castelló de la Plana, Springer.

Rice, C. (2018) Rivers, roads, and ports. In C. Holleran and A. Claridge (eds), A Companion to the City of Rome: 199-217. Hoboken/Chichester, Wiley Blackwell.

Rickman, G.E. (2002) Rome, Ostia and Portus: the problem of storage. Mélanges de l'École Française de Rome 114: 353-62.

Roggio, B. (2010) Roma: uno studio diacronico delle trasformazioni dell'area ostiense. Università degli studi di Roma "Tor Vergata", Ph.D. thesis.

Salomon, F., Goiran, J.-P., Bravard, J.-P., Arnaud, P., Djerbi, H., Kay, S. and Keay, S. (2014) A harbour-canal at Portus: a geoarchaeological approach to the Canale Romano: Tiber delta, Italy. Water History 6: 31-49.

Salomon, F., Goiran, J.-P., Pannuzi, S., Djerbi, H. and Rosa, C. (2016) Long-term interactions between the Roman city of Ostia and its paleomeander, Tiber Delta, Italy. Geoarchaeology: An International Journal 32: 215-29.

Scheidel, W. and Meeks, E. (2012) ORBIS: The Stanford Geospatial Network Model of the Roman World. http://orbis.stanford.edu (accessed 15 May 2019).

Scrinari, V.S.M. (1979) Le navi del Porto di Claudio. Rome, Tipografia Centenari. 
Smith, C. (2018) Historical overview: from city-state to Christian center. In C. Holleran and A. Claridge (eds), A Companion to the City of Rome: 29-52. Hoboken (NJ)/Chichester, Wiley Blackwell.

Smith, J.T. (1997) Roman Villas: A Study in Social Structure. London/New York, Routledge.

Tarquini, S., Vinci, S., Favalli, M., Doumaz, F., Fornaciai, A. and Nannipieri, L. (2012) Release of a 10-m-resolution DEM for the Italian territory: comparison with global-coverage DEMs and anaglyph-mode exploration via the web. Computers and Geosciences 38: 168-70.

Taylor, R. (2018) The soft-core city: ancient Rome and the wandering Tiber. In T. Way (ed.), River Cities, City Rivers: 49-75. Washington, DC, Harvard University Press.

Tchernia, A. (2000) Subsistence à Rome: problèmes de quantification. In C. Nicolet, R. Ilbert and J.-C. Depaule (eds), Mégapoles méditerranéennes: géographie urbaine rétrospective. Actes du colloque organisé par l'École française de Rome et la Maison méditerranéenne des sciences de l'homme: 751-60. Maisonneuve/Rome/Aix-en-Provence/Paris, Ecole française de Rome Maison Méditerranéenne des Sciences de l'Homme.

Wheatley, D. and Gillings, M. (2002) Spatial Technology and Archaeology: The Archaeological Applications of GIS. London, Taylor and Francis.

Wilson, A., Schörle, K. and Rice, C. (2012) Roman ports and Mediterranean connectivity. In S. Keay (ed.), Rome, Portus and the Mediterranean: 367-92. London, The British School at Rome and the Soprintendenza Speciale per i Beni Archeologici di Roma, sede di Ostia.

Witcher, R. (2005) The extended metropolis: urbs, suburbium and population. Journal of Roman Archaeology 18: 120-38.

Zoido Naranjo, F., de la Vega Benayas, S., Morales Matos, G., Mas Hernández, R. and Lois González, R.C. (2000) Diccionario de geografía urbana, urbanismo y ordenación del territorio. Barcelona, Ariel. 